\title{
Non-discrimination clauses: their effect on British retail energy prices
}

Article

Accepted Version

Waddams Price, C. and Zhu, M. (2016) Non-discrimination clauses: their effect on British retail energy prices. The Energy Journal, 37 (2). ISSN 1944-9089 doi:

https://doi.org/10.5547/01956574.37.2.cpri Available at https://centaur.reading.ac.uk/69059/

It is advisable to refer to the publisher's version if you intend to cite from the work. See Guidance on citing.

To link to this article DOI: http://dx.doi.org/10.5547/01956574.37.2.cpri

Publisher: International Association for Energy Economics

All outputs in CentAUR are protected by Intellectual Property Rights law, including copyright law. Copyright and IPR is retained by the creators or other copyright holders. Terms and conditions for use of this material are defined in the End User Agreement.

\section{www.reading.ac.uk/centaur}

\section{CentAUR}

Central Archive at the University of Reading

Reading's research outputs online 


\title{
Non-discrimination clauses: their effect on GB retail energy prices ${ }^{1}$
}

\author{
Catherine Waddams Price ${ }^{2}$ and Minyan Zhu ${ }^{3}$
}

\begin{abstract}
UK governments and the energy regulator have shown increasing concern about the health of competition in the residential energy market, following their pioneering deregulation at the end of the last century. We identify the effects of introducing the nondiscrimination clauses in 2009, a major regulatory intervention and the first since deregulation. We explore the effect of this intervention on the price movements of the six major players, and find that the nature of competition in the industry has changed, with less effective rivalry between the regional incumbents and large regional competitors following the intervention; companies seem to have 'retreated' to their home regions, leaving a market where pricing behaviour resembles more closely a duopoly between British Gas and the regional incumbent.
\end{abstract}

Key words: regulation, energy, non-discrimination, Vector Autoregressive Model

\footnotetext{
${ }^{1}$ We gratefully acknowledge funding from the ESRC, and many helpful discussions with and suggestions from Stephen Davies, Maxine Frerk, Morten Hviid, Stephen Littlechild, and Ben Smithers, while we retain sole responsibility for the analysis and its interpretation. We are grateful for comments from colleagues at the Centre for Competition Policy, and participants in discussions at the Australian Competition and Consumer Council.

${ }^{2}$ C.waddams@uea.ac.uk; Centre for Competition Policy, University of East Anglia, Norwich NR4 $7 \mathrm{TJ}, \mathrm{UK}$.

${ }^{3}$ Minyan.zhu@nottingham.ac.uk, Business School University of Nottingham, NG8 1BB (formerly at Centre for Competition Policy, UEA).
} 


\section{Introduction and history}

2008 marked a change in the GB energy regulator's attitude to the residential retail market. While it had previously pioneered and championed competition in this sector, it became increasingly concerned with the fairness of the competitive process, seeing the competition glass much more as half empty than half full. We explore the effect of this policy shift on the industry by identifying changes in the way that the major suppliers to the retail market have set their prices. The debate continues to be driven by political and consumer concerns, and to be fuelled by political intervention, ranging from ex cathedra statements by the prime minister that he would ensure that everyone was on the cheapest tariff in the market (Cameron, 2012) to the promise of a seventeen month price freeze if the Labour party is elected in 2015 (Miliband, 2013), and counter moves from the government to remove taxes which fund energy efficiency measures from prices (Osborne, 2013).

Until 1996, each residential consumer in Great Britain was served by two monopolists - a national gas supplier, British Gas ${ }^{4}$ (known as Scottish Gas in Scotland), and one of fourteen regional electricity suppliers. The retail energy markets were opened between 1996 and 1999, and each of these previous monopoly suppliers entered each others' markets. At the same time electricity distribution networks were separated ${ }^{5}$ from retail operations (gas networks had been separated from gas retail through the creation of Centrica in 1997). A process of consolidation through takeover and exit led by 2002 to the emergence of five major successors to the electricity incumbents, each previously the monopoly supplier in two or three regions, and British Gas. These firms dominated supply, with other entrants gaining less than $1 \%$ of the market over

\footnotetext{
${ }^{4}$ Piped gas is not available in many rural areas, so around $17 \%$ of households do not use gas.

${ }^{5}$ The Utilities Act 2000 required the legal separation of retail and distribution businesses, and ownership separation has since followed in half the fourteen regions.
} 
the next decade, and with no long term survivors amongst these entrants, who were taken over or exited the market. The regulator reduced barriers to entry after some years, and by early 2014 there were several new entrants, whose joint share of the market had grown to 5\% (Ofgem, 2014), the largest for many years. Nevertheless supply continues to be dominated by the five previous electricity incumbents and the former gas incumbent, known collectively as the Big $\mathrm{Six}^{6}$.

Analysis of energy prices from these firms at the time when the last price caps were removed from the retail sector ${ }^{7}$ in 2002 showed that while parts of the market were competitive, incumbent mark-ups remained, suggesting considerable consumer inertia; and price variations did not reflect differences in costs for consumers using prepayment (pay as you go) meters, indicating considerably less well developed competition in this sector (Salies and Waddams Price, 2004). The removal of price caps on incumbent suppliers coincided with the end of a period of consolidation in the industry which culminated in the establishment of the Big Six. In the three years following that consolidation the surviving companies chose price structures which effectively separated the market, with some offering tariffs particularly attractive for users of large quantities, and others offering tariffs which were better for users of small amounts of electricity (Davies et al., 2014). These appeared to evolve from the repeated interaction of the companies in the regional electricity and national gas markets rather than from any explicit collusion; they are consistent both with innovation in the market and as an effective way of softening "headon" competition between suppliers. The very rapid increase in wholesale energy costs after 2005 seems to have destabilised this tariff pattern.

However one pattern which continued in these later years, and which resulted in substantial regulatory intervention, was the persistence of an 'incumbent mark-

${ }^{6}$ These are British Gas, EdF Energy, E.On, RWE NPower, Iberdrola, Scottish and Southern Energy (SEE).

${ }^{7}$ Distribution and transmission prices remain regulated 
up' of around 10\%, similar to those identified by Salies and Waddams Price (2004) when the price caps were removed in 2002. In its 2008 Energy Supply Probe, the regulator identified such price differences between regions as a symptom of competition concern and a major problem for fairness; they introduced a new license condition $(25 \mathrm{~A}$, which we refer to as the nondiscrimination clause, or NDC), to prevent companies charging higher mark-ups to consumers in their home regions than in others ${ }^{8}$. The regulator pursued this policy on the grounds of fairness, and a concern that vulnerable consumers were more likely not to have switched, and so be paying higher prices (Ofgem, 2008), despite acknowledging potential damage to competition (Ofgem 2009). The regulator was also motivated by complaints from potential entrants from outside the industry that the heavy discounts offered by major players out of their home markets acted as a barrier to entry to smaller players without a home base where they could charge higher prices to recoup their costs. Following representations from the Big Six, the large players were allowed to compete through special offers to attract new consumers, so long as these were temporary; as predicted ${ }^{9}$, such special offers resulted in a proliferation of tariffs, and concerns that consumers, particularly vulnerable groups, might not fully understand the temporary nature of those offers, which were generally replaced by higher 'default' tariffs when they expired..

The 2008 supply probe also introduced other measures to improve competition and remove barriers to switching, including an annual statement to prompt consumer awareness, tighter rules on mis-selling of energy and restrictions on how far companies could prevent switching by consumers in debt. However after accumulated evidence that the market had been damaged by the NDC

\footnotetext{
${ }^{8}$ The regulator simultaneously implemented a European directive, requiring that differences in the terms and conditions offered in respect of different payment methods is cost reflective, in license condition SLC 27.2A. While this is not the focus of our analysis, we comment briefly on its potential effect in the conclusions.

${ }^{9}$ See for example the evidence from Waddams (2009) to the Ofgem consultation.
} 
(Hviid and Waddams Price, 2012; Littlechild, 2012) the regulator reversed its decision to renew the clauses in 2012, but announced continued vigilance in this regard and introduced a number of other constraints on tariffs to simplify choices for consumers.

In this paper we examine the evolution of electricity price movements of one major tariff type between 2005 and 2013, focusing on the interaction between different firms in the market. Energy expenditure almost doubled between 2005 and 2013 (from about $£ 250$ to $£ 450$ a year in real terms ${ }^{10}$ ) and prices have recently become the focus of considerable political attention (Miliband, 2013; Cameron, 2012). We find that the pattern by which firms set their prices changed at the time of the NDC, consistent with concerns that this intervention has adversely affected the nature of competition in the industry. This supply side change has been mirrored by falling consumer engagement in the market, with switching rates halving between their peak in 2008 and 2013 (Department of Energy and Climate Change, 2014a $\mathrm{a}^{11}$ ). The next section presents descriptive statistics on price changes in the residential market and explains the data and their limitations. Section 3 uses causality tests to identify price leadership, and section 4 discusses the policy implications and concludes.

\section{Tariffs and data}

Since 2005, the level of retail energy prices has risen in real terms, but with some decreases as well as increases. This rising trend in prices is shown in figure 1 for each of the main suppliers, using an unweighted average across all regions of the annual bill of a direct debit electricity consumer on the standard offline tariff (i.e. the main tariff published for that payment method, rather than

\footnotetext{
10 These prices are deflated using CPI and May 2005 as the base.

${ }^{11}$ Switching rates rose dramatically inn the fourth quarter of 2013, though not the the height achieved in 2008, but fell back again in the first quarter of 2014.
} 
one attracting special conditions ${ }^{12}$ ), using a medium quantity of electricity ${ }^{13}$. At the end of December 2013, 55\% of residential consumers paid by direct debit, of whom about $65 \%$ were on standard tariffs of the kind reported here (Department of Energy and Climate Change, 2014b).

Figure 1: Annual electricity charges by 'Big Six'

Direct Debit consumer using 3300kWh per annum (deflated using $\mathrm{CPI}^{14}$, average across regions)

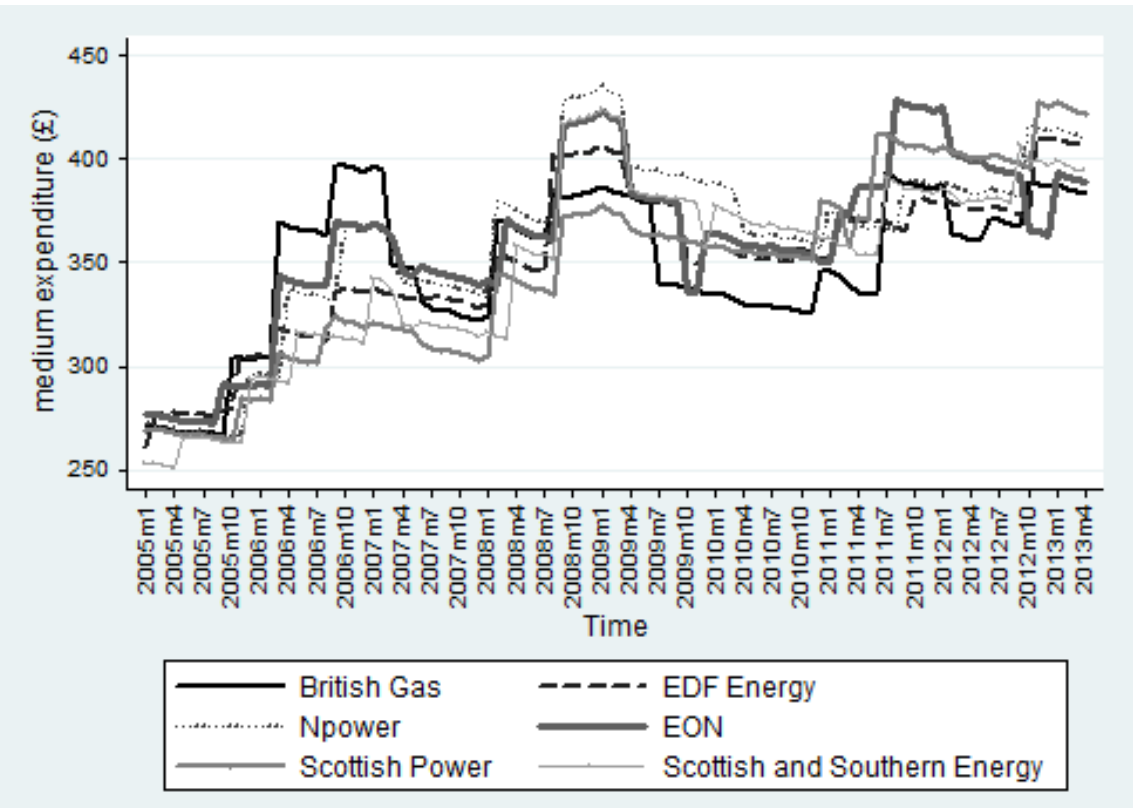

Data Source for all graphs and analysis: Consumer Focus Price Comparison Factsheets and authors' calculations

Each of these Big Six suppliers is similar in terms of turnover and structure, all with both generation and retail operations in electricity supply (though only British Gas is vertically integrated in gas). Of the 26.7 million domestic electricity accounts in December 2007, the market shares of the Big Six ranged from $12 \%$ (Scottish Power, incumbent in only two regions) to $19 \%$ (Scottish and Southern Energy, incumbent in three regions) and 22\% (British Gas) (Ofgem, 2008 p. 32). No small entrant survived throughout the period of analysis, and at

\footnotetext{
${ }^{12}$ Special conditions might include fixed prices for a specified period, 'green' tariffs which claim environmental benefits or other special benefits or conditions, including potential exit fees.

${ }^{13} 3,300 \mathrm{kWh}$ was defined by Ofgem as the annual consumption of a 'typical' household with a medium level of energy demand (Ofgem, 2011)

${ }^{14}$ All the price figures are deflated using CPI (May 2005=100).
} 
the time of the Energy Supply Probe in 2008, four such entrants shared less than $0.3 \%$ of the market accounts, though their share had grown to 5\% by 2014 (Ofgem, 2014).

Figure 2 shows these data grouped according to type of supplier in each region, namely incumbent (which varies between regions), cheapest and median offer from among the rest of the Big Five (i.e. other than the incumbent and British Gas) and British Gas. To distinguish between these companies and smaller firms who have entered the industry from outside, we label these large companies with regional electricity incumbency regions as 'majorsaway' when operating outside their home areas; and identify the best majoraway as the one which charges least for the medium consumption level on the standard offline direct debit tariff. The gap between the average incumbent and median majoraway bills before 2008 illustrates the background to the regulator's introduction of the NDC. The regulator had found that in the period leading up to 2008 suppliers had charged around ten per cent more in incumbent areas (where consumers stayed with it as default provider unless they switched provider) than in other areas (where the majoraway had to tempt consumers away from the incumbent provider in that region). Of course the identity of the cheapest (and median) majoraway varies both between regions and across time periods, and identifies the best challenge to the incumbent at any one time. 
Figure 2a: Annual electricity charges by type of supplier

Direct Debit consumer using 3300kWh per annum (deflated using CPI, average across regions)

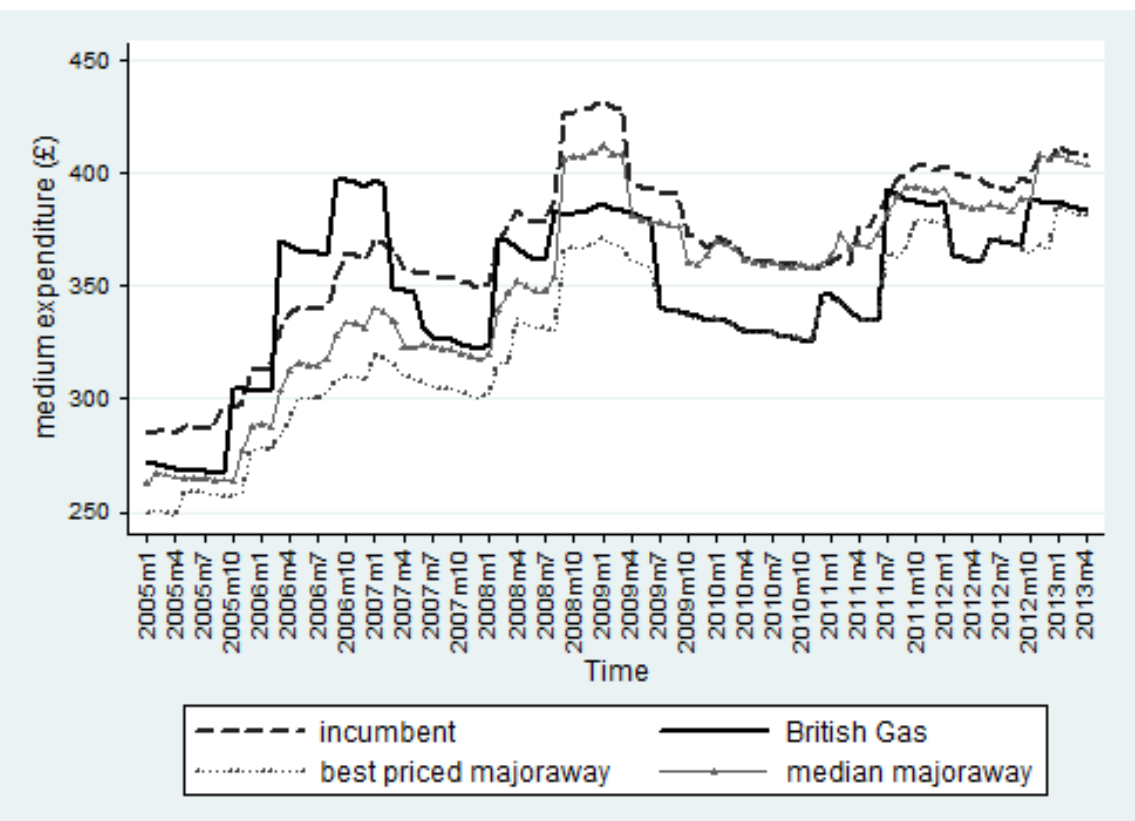

Figure 2b: Annual electricity charges by type of supplier - Eastern Region Direct Debit consumer using 3300kWh per annum (deflated using CPI)

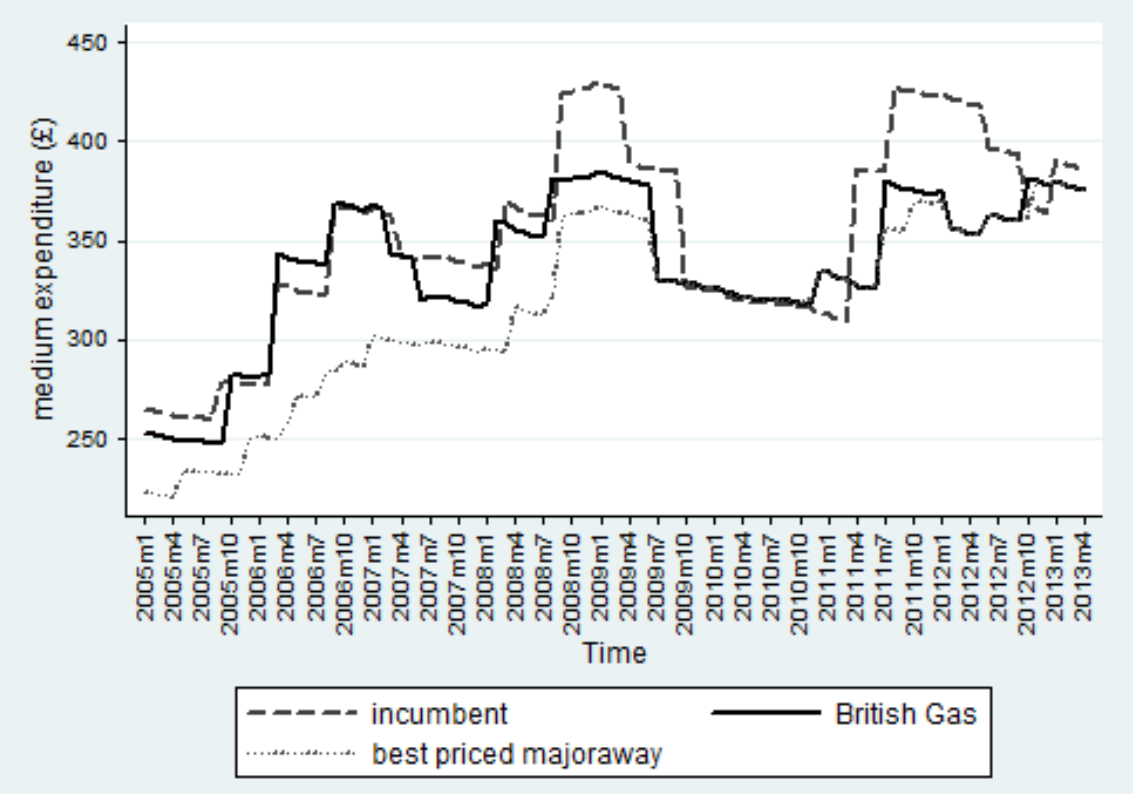

Figure 2a shows the convergence of prices following the imposition of the NDC in 2009, and these reductions in differentials are illustrated in more detail in 
figures 3 to 5 . We see this pattern even more clearly in some individual regions, for example the Eastern region, shown in Figure 2b. Price differences between incumbent and the best priced majoraway started to fall in early 2009 and reached their lowest point, where they remained for the following two years, around April 2011 (figure 3). The difference between the charges of the incumbent and British Gas changed considerably over the period. After a period of relatively high prices, British Gas made significant price reductions in 2007 to close the gap with incumbents, and by early 2008 its prices became more competitive for electricity than those of incumbents. The average incumbentBritish Gas price difference has stayed above zero and relatively flat since then (figure 4). The British Gas strategy is reflected in price differences between British Gas and the best majoraway (figure 5), with a decreased gap after the price cuts, and a further decrease in price differences after the imposition of the NDC (figure 5).

Figure 3 Difference in annual electricity charges between incumbent and best majoraway

Direct Debit consumer using 3300kWh per annum (deflated using CPI, average across regions)

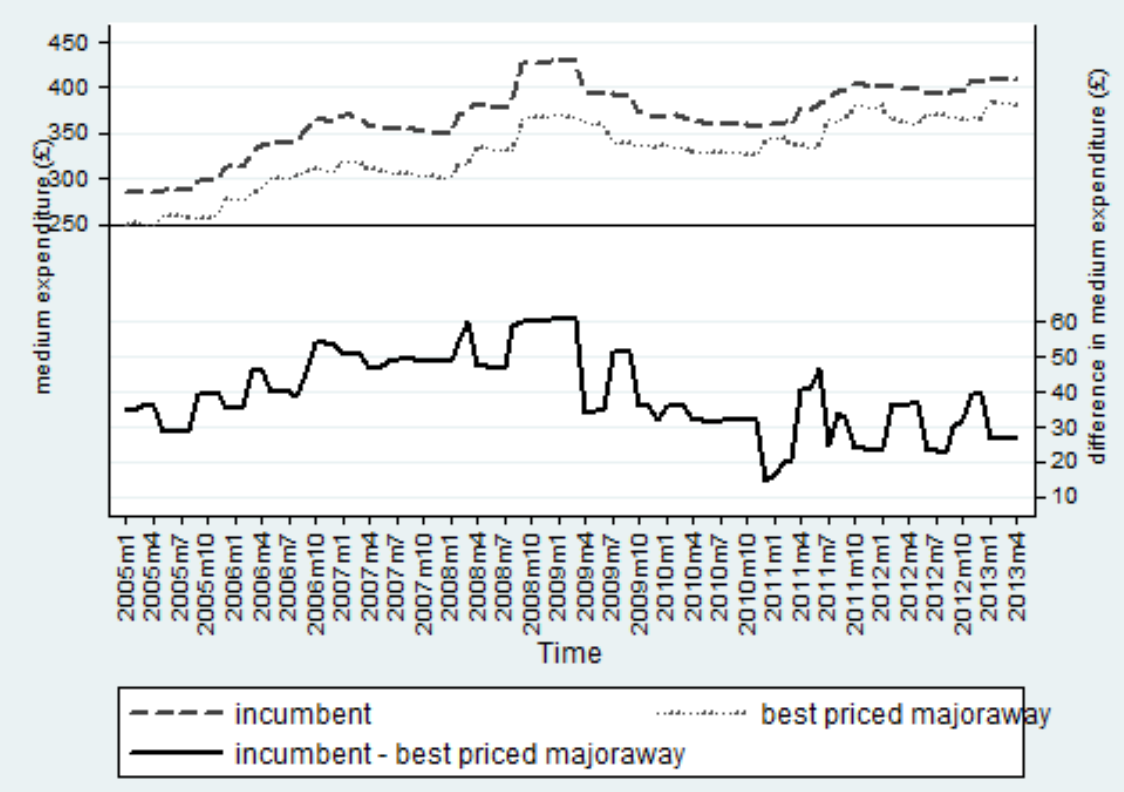


Figure 4 Difference in annual electricity charges between incumbent and British Gas

Direct Debit consumer using 3300kWh per annum (deflated using CPI, average across regions)

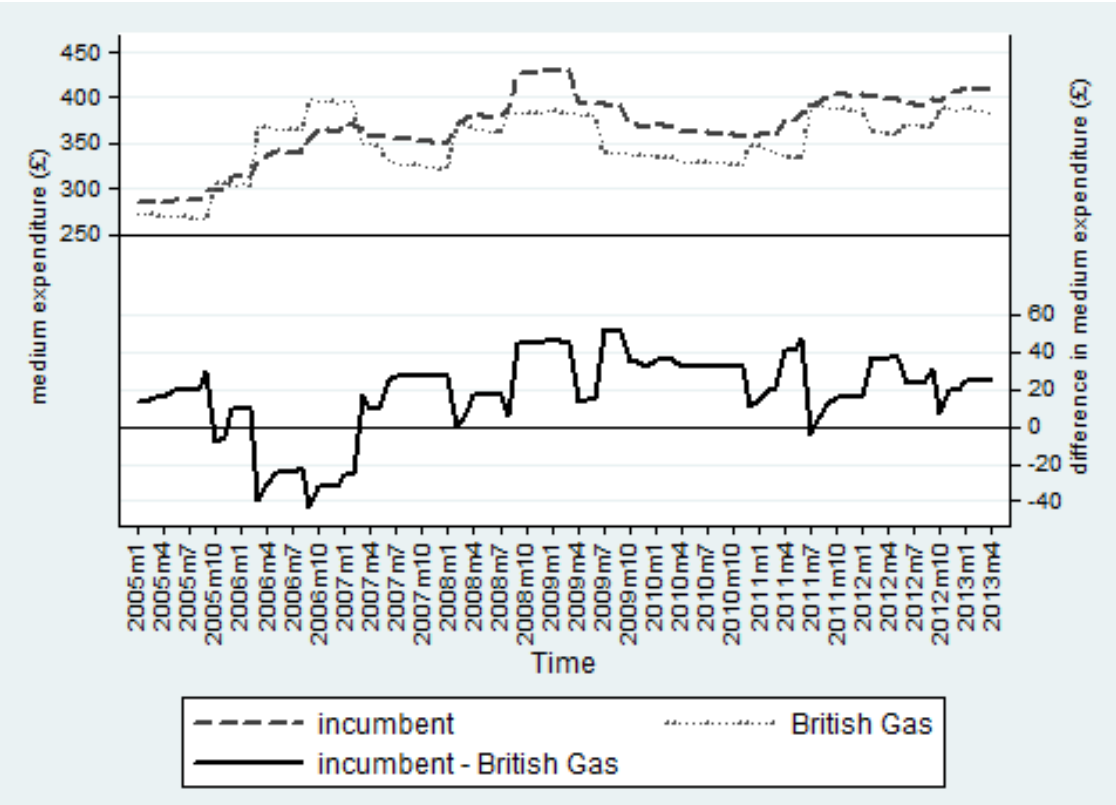

Figure 5 Difference in annual electricity charges between British Gas and best majoraway

Direct Debit consumer using 3300kWh per annum (deflated using CPI, average across regions)

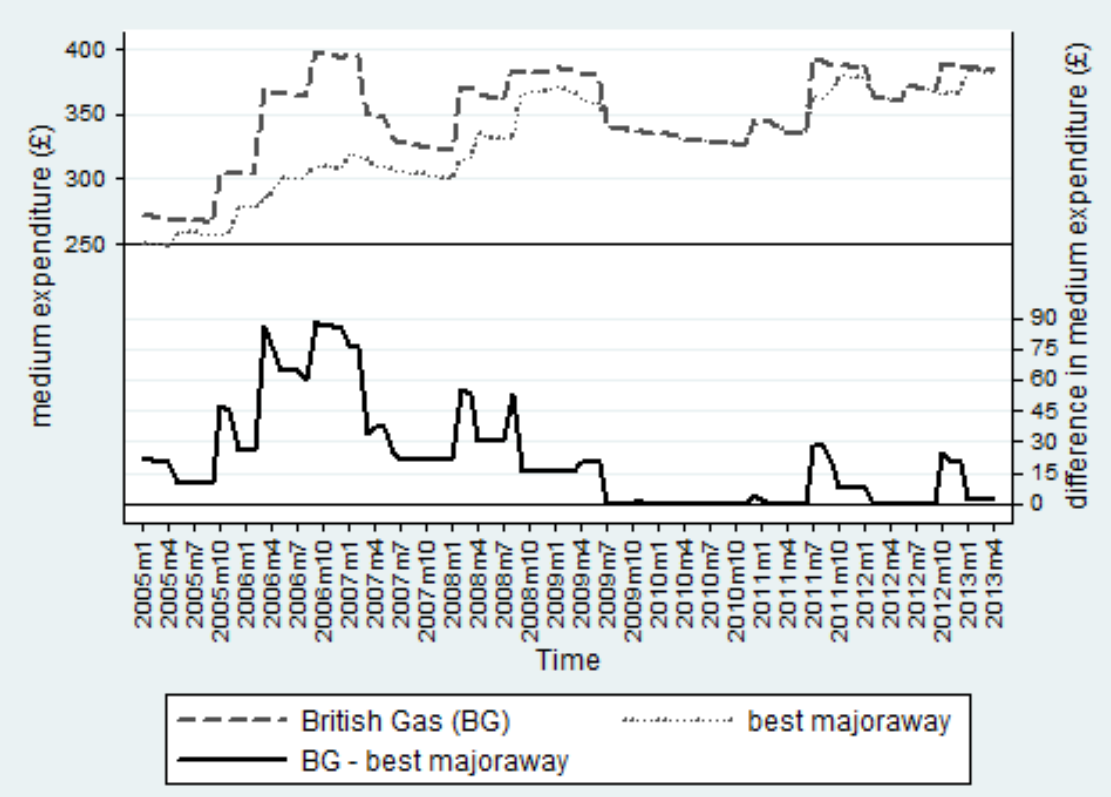


We explore the implications of these differences for competition in the retail market. Hviid and Waddams Price (2012) showed that because the 'strong' market of each of the major players (where they were traditional incumbents) coincided with the 'weak' markets of competitors (where they had no incumbency base), and British Gas took a national approach, the NDC was likely to lead each company to concentrate on its home markets and compete less aggressively in others, resulting in higher prices.

The initial high level data presented above suggest that this is precisely what has happened. Price differentials between standard tariffs have indeed fallen; since companies were allowed to introduce special offers, these increased dramatically, enabling the companies to segment the market, and focus their competitive actions away from the standard tariffs. Switching rates have fallen, confirming widespread evidence (Ofgem, 2008, p.152, Giulietti et al., 2005, Flores and Waddams Price, 2013, Waddams Price et al., 2013) that potential price gains are the main drivers of consumer activity in the residential energy market. Published figures at an aggregate level, and monthly figures obtained from the regulator at regional level, show a dramatic fall in switching rates following the introduction of the non-discrimination clauses. If the other policies which the regulator introduced at the same time to remove barriers to switching were effective, these figures may understate the fall in switching due to the NDC alone. On the other hand, companies gradually withdrew from direct marketing from 2011 onwards, which itself is likely to have reduced switching rates.

Because of the volatility of upstream costs, particularly wholesale energy prices, it is difficult to identify directly whether price differentials between incumbents and majorsaway narrowed because incumbent prices fell (as the regulator intended) or because majoraway prices rose as competitive constraints 
weakened. However figures from the regulator on the profitability of the Big Six seem to indicate the latter, as profit margins rose from levels near zero when the clauses were introduced, to margins of just over $£ 100$ per consumer in 2013 (Ofgem, 2013).

In this paper we explore the changes in companies' pricing behaviour which followed the introduction of the package of reforms arising from the 2008 Energy Supply Probe and the NDC. We do this by analysing the pattern of prices amongst the Big Six companies for their 'standard' electricity customers (off line, of average quantities, and paying by direct debit, the payment method used by most consumers switching energy supplier). These data are taken from price sheets published by Consumer Focus which show the main tariffs for the Big Six; while later information includes online tariffs, the earlier publications do not, so we restrict our analysis to offline tariffs ${ }^{15}$. Since the nondiscrimination tariffs provided incentives for companies to use special offers to compete (because these were not tied to prices charged in home markets), competition shifted somewhat to these non-standard tariffs, which are not published. To the extent that companies no longer expect to recruit new consumers through standard tariffs, our analysis will therefore overstate any dampening effect on competition; we return to this in our conclusions.

\footnotetext{
${ }^{15}$ Online tariffs offer discounts to customers who agree to receive their bills electronically, rather than via paper and post. Arrangements range from simple viewing of bills online to requiring customers to submit meter readings online. In 2008 around 1.3 million GB customers used online tariffs, just under $5 \%$ of households.
} 


\section{Patterns of price changes and causality tests}

This section analyses differences in suppliers' pricing behaviour; to explore the effect of the NDC, we divide the data into two subsamples, before and after the introduction of the clauses. We omit the period from July 2008 to August 2009 as a transition period, since discussions about the new conditions started around June 2008 and were already affecting differentials before the publication of the Probe in October 2008, though the NDC was not formally imposed until September 2009.

\subsection{Model Specification}

We examine the behaviour of the major players in each region and build on the predictions of Hviid and Waddams Price (2012) to form our hypothesis that majorsaway will compete less aggressively with the established incumbent out of their home regions after the imposition of the NDC than they did before. If the majorsaway were exerting competitive pressure on the incumbents before the NDC, we would expect to see a negative relationship between the price changes of the incumbent and those of the best priced majoraway, as the latter moderates its own price increases to gain customers, so imposing some constraint on the incumbent. In contrast, if the introduction of the NDC weakened this constraint, the majorsaway would then take advantage of any increase in the incumbent's price to raise their own tariffs out of region, which would allow them to raise prices in their home areas too. By linking home and out of area prices, the NDC provides an incentive for majorsaway to raise their tariffs. Thus instead of constraining their own price increases to attract additional consumers, which would result in a negative relationship between the price changes, the majorsaway would follow the incumbent's price increases, so the relationship between the price increases would cease to be negative, and might even become positive. To support our hypothesis we therefore seek 
evidence that the relationship between the incumbent's and the best majoraway's price changes is negative before the non-discrimination clauses are imposed (reflecting some competitive constraint on the incumbent's price from the best majoraway) and becomes less negative after they are introduced.

This hypothesis leads us to examine the relationship between the price changes of the major players in each region, focusing on that between the incumbent and the best majoraway ${ }^{16}$, and taking account of other price changes and relevant factors. We use a Vector Autoregressive Model $\left(\mathrm{VAR}^{17}\right)$ model to identify patterns between price changes. An advantage of using the VAR model is that it treats all variables as endogenous, and does not require prior restrictions on the model. We then use Granger causality tests ${ }^{18}$ to assess the statistical significance of how price movements by each of the players in the market help to predict the subsequent price changes of others.

A standard VAR, written as $\operatorname{VAR}(p)$, is a model in which $K$ variables are specified as linear functions of $p$ of their own lags, $p$ lags of the other $K-1$ variables, and additional exogenous variables. We specify a p-order VAR model of price changes introduced by the incumbent, British Gas and the best majoraway, with exogenous variables including seasonal dummies and a time trend as follows:

$y_{t}=v+A_{1} y_{t-1}+\ldots+A_{p} y_{t-p}+B_{0} x_{t}+u_{t}$

\footnotetext{
${ }^{16}$ Since our analysis concerns the behaviour of the Big Six, who controlled $98 \%$ of the market during this period $(100 \%$ of it for most of it) we omit other entrants from this analysis. The identity of the best majoraway in each region is likely to change from time to time, so this does not necessarily represent changes in prices offered by a single company, unlike price changes for British Gas and the incumbent.

${ }^{17}$ Strictly speaking, the model is a VARX model, since it includes exogenous variables (quarterly dummy variables and a time trend), but we use the more familiar VAR acronym in the text.

${ }^{18} \mathrm{~A}$ variable $\mathrm{x}$ is said to Granger-cause a variable $\mathrm{y}$ if, given the past values of $\mathrm{y}$, past values of $\mathrm{x}$ are useful for predicting y. After fitting a VAR model (see the above) for each equation of each endogenous variable that is not the dependent variable in that equation, the test computes and reports Wald tests that the coefficients on all the lags of an endogenous variable are jointly zero. The null hypothesis is that each of the endogenous variables does not Granger-cause the dependent variable in that equation.
} 
Where $\quad y_{t}=\left(\Delta p_{t}^{M}, \Delta p_{t}^{B}, \Delta p_{t}^{I}\right)^{\prime}$ is a $3 \times 1$ vector, and $\Delta p_{t}^{M}, \Delta p_{t}^{B}, \Delta p_{t}^{I}$ are the price changes of the best majoraway, British Gas and incumbent, respectively, in period $t$;

$A_{1}$ to $A_{p}$ are $3 \times 3$ matrices of the parameters to be estimated;

$x_{t}{ }^{\prime}$ is a $4 \times 1$ vector of exogenous variables, namely quarterly dummy variables and a time trend;

$B_{0}$ is a $3 \times 4$ matrix of coefficients;

$v$ is a $3 \times 1$ vector of parameters (constants);

and $u_{t}$ is assumed to be white noise.

If the $u_{t}$ are distributed with a zero mean, i.i.d. vector process, and $y_{t}$ and $x_{t}$ are covariance stationary and are not correlated with the $u_{t}$, consistent and efficient estimates of the $B$, the $A$ and $v$ are obtained via seemingly unrelated regression, yielding estimators that are asymptotically normally distributed.

In the above VAR model, effectively we have 3 equations estimated, namely of the current price change of the best majoraway, incumbent and British Gas respectively, with the same regressors, i.e. the price changes of the same players and the same exogenous variables in each equation on the right hand side.

To determine the selection of lag length (the value of $p$ ), we use a sequence of $\log$ likelihood ratio (LR) tests using a maximum of four lags ${ }^{19}$. We also

\footnotetext{
${ }^{19}$ For a given lag $p$, the LR test compares a VAR with $p$ lags with one with $p-1$ lags. The null hypothesis is that all the coefficients on the $p t h$ lags of the endogenous variables are zero. To use this sequence of LR tests to select a lag order, we start by looking at the results of the test for the model with the most lags. The first test that rejects the null hypothesis is the lag order selected by this process (also see Lutkepohl, 2005 p.143-144 for more information on this procedure). We also do another set of LR tests post estimation which are reported in the appendix.
} 
implement a Lagrange-multiplier (LM) test for autocorrelation in the residuals of the VAR models (as presented by Johansen, 1995) to ensure that the disturbance is not auto-correlated. Test statistics are reported in the appendix. LM tests with a maximum of five lags are implemented that show no hint of model misspecification for all regions. Statistics for two lags are reported in the appendix. Note that before we estimate the VAR model, Dicky-Fuller unit root tests confirm that all price changes are stationary in each region. Prior to the VAR model specification, we also conducted cointegration tests and do not find robust evidence of cointegration of the price series of the suppliers ${ }^{20}$ in the regions in each period.

After fitting the VAR model, we conduct Granger causality tests to test the statistical significance of causality from one supplier's price changes to another. For instance, $I_{t p} \rightarrow M_{t}$ in columns 2 and 3 of tables 1 and 2 reports whether past price changes of the incumbent influence the current price changes of the best majoraway.

Establishing that past price changes of the incumbent help to explain the current price changes of the majorsaway is not sufficient, in itself, to confirm a causal relationship between the price changes of the incumbent and those of the best majoraway. As noted above, one advantage of using VAR is that no formal theory is required for the formulation of the model. But this also means that by design the Granger causality tests are predicated on a model that may be missing intervening variables. In other words, the finding of a 'causal' effect might result from the omission of a variable that is correlated with both of the left-hand-side variables. For instance, to prove the causal relationship between incumbent and the best majoraway, we would also have to demonstrate that there were no other

${ }^{20}$ Note that if prices are cointegrated between the suppliers, the VAR model may be mis-specified as it ignores a long-term adjustment term in the specification and only focuses on short-term adjustments. In the absence of co-integration, VAR specification is appropriate. 
intervening explanations that would explain price movements of both the incumbent and the best majoraway. The methodology used here can only show that the evidence is consistent with our hypothesis. We demonstrate this in greater detail at the end of the next subsection.

\subsection{Results}

Table 1 shows the results of the VAR model and Granger causality tests in Period 1, before June 2008. The coefficients reported measure the effect of one set of price variations on the price changes being explored, while controlling for all other variables (including previous price changes by both the supplier itself and other actors in the market, a time trend and seasonal factors). Columns 2, 4, 6 and 8 show the coefficients of each of the equations, and columns 3, 5, 7 and 9 the results of the corresponding Granger causality tests ${ }^{21}$. Causalities of price changes which are not significant under the Granger causality tests are not reported $^{22}$. In seven out of 14 regions, Granger causality tests (column 3) confirm that the best majoraway responded to the incumbent's price changes in the two previous periods (column 2). In all these cases the best majoraway responded in the opposite direction to the incumbent's price changes: as the incumbents accelerated their price increases (decreases) the best majorsaway moderated their price changes. For instance, in the Midlands region, if the incumbent had added to its price increase by $£ 100$ in the previous periods, the best majoraway would typically have responded by reducing its price increase by around $£ 23.50$.

The pricing responses of the best majoraway to incumbents can be interpreted as the following strategy. If the incumbent accelerates its price increases, the best majoraway will slow its price increases to attract the incumbent's customers;

${ }^{21}$ The coefficients of lagged price of best majoraway itself are not reported in the table.

${ }^{22}$ For full results and diagnostics please see the appendix. 
whereas when an incumbent slows down its price increase (say after a price rise), the best majoraway will accelerate its price increase to raise more revenue from existing customers, and perhaps to give it more scope for undercutting the incumbent in the next round of incumbent price increases. This suggests that other majors were providing some constraint on incumbents' charges, notwithstanding the incumbent mark-up.

The effect of British Gas price changes on those of the best majoraway shows more positive coefficients (columns 4 and 5); in twelve of the regions, an acceleration in price changes by British Gas is associated with an acceleration in the price changes of the best majoraway (column 4), confirmed by Granger causality tests (column 5). British Gas price changes also had a positive effect on the incumbents' price changes in nine of the 14 regions (column 6), again confirmed by Granger causality tests (column 7). However the influence of the incumbent's price changes on British Gas is in the reverse direction in two regions (column 8). These statistical results from the VAR model and Granger causality tests show evidence of price leadership by British Gas in this period, since the price changes of both the best majorsaway and of the incumbents tended to follow those of British Gas.

The pattern of Granger causality between price changes shows a striking relationship with ownership of the incumbent in each region,. For example, the seven regions where the incumbent's price changes have a negative influence on those of the best majoraway include all three regions where RWE Npower owns the incumbent, all three where E.On does so, and one of the three where SSE owns the traditional supplier. The two regions where the best majoraway's prices are not influenced by British Gas are the other two of the three where the incumbent is SSE. Such ownership patterns are also reflected in the influence on incumbents' price changes themselves by British Gas. The five regions where 
Granger causality tests find no evidence of causality comprise all those where EdF or Iberdrola owns the incumbent. The reverse direction of causality, where the incumbent's price changes influenced those of British Gas, occurs only in two regions, in both of which the incumbent is SSE.

Table 2 shows the results from the VAR model and Granger causality tests in Period 2, after September 2009, when the NDC was imposed. The negative response of the price changes of the best majoraway to those of the incumbent is seen in only one region, Southern, a region where this was not evident in period 1. In the three regions where the incumbent is owned by NPower there is no evidence that the best majoraway responds to the incumbent's price changes, compared with a negative result in period 1; in the three regions where the incumbent is owned by E.On the relationship has gone from negative to positive; in the two regions where Iberdrola owns the incumbent the relationship has gone from insignificant to positive; and there are mixed changes in the regions where the incumbents are owned by EdF or SSE. However the general pattern is that the incumbents' price changes now influence those of the best majorsaway in a more positive way (nine of the fourteen regions), indicating that the best majorsaway are imposing less of a constraint on the incumbents' price changes than they were in period 1. For instance, in the Manweb region, if the incumbent adds to its previous price increase by $£ 100$, the best majoraway will follow and add to its price increase by between $£ 36$ and $£ 42$. Compared to the pricing behaviour in period 1 , the change in the pricing pattern in period 2 implies that majorsaway are showing signs of retreating to their incumbent regions to focus on the revenue of their own incumbent customers, rather than recruiting customers in non-incumbent regions.

This is consistent with the hypothesis derived from the theoretical predictions (outlined above and in Hviid and Waddams Price, 2012). If the majorsaway had 
continued with the pricing strategy displayed in period 1, the NDC clauses would require any constraint on price increases in suppliers' non-incumbent areas to be matched by a similar deceleration of price increases in their incumbent regions. The NDC thus deters the best majorsaway from exerting their previous constraint on regional incumbents. Since we have omitted the period when the price adjustments were implemented in response to the NDC, these results capture the mutual response of companies after the clause was imposed, rather than the process of compliance itself.

Columns 4 and 5 of table 2 show that past price changes of British Gas continue to lead the current price changes of the best majorsaway in 11 of the 14 regions, but the exceptional regions have changed. After the NDC it is the three regions where the incumbent is owned by NPower which are the exception (rather than the two where the incumbent is owned by SSE).

A major change between the two periods is in the way that price changes by British Gas and the incumbent influence each other. After the nondiscrimination clause, column 6 in table 2 shows that price changes of the incumbent follow those of British Gas in five regions, with the statistical significance of the causality confirmed by Granger causality tests (column 7). Note that in the period before the NDC was introduced, the causality from British Gas to the incumbent is significant in nine regions (see table 1 column 6 and 7). Column 8 in table 2 shows that price changes of British Gas follow those of the incumbent in five regions (confirmed by Granger causality tests, column 9 in table 2), while in the period before the NDC was discussed, the causality was only significant in two regions, and in a negative direction, i.e. British Gas imposed some constraint on the incumbent in these regions. After the imposition of the clauses, in half the regions the coefficients are more positive, with no qualitative change in the other regions. Again there is a strong ownership 
pattern: the seven affected regions are all those where the incumbent is owned by E.On or Iberdrola, along with two of the three owned by SSE. Observation of British Gas prices shows that it continued to follow a national policy, so we would not expect its behaviour to moderate the competition softening effect of the NDC. We have no reason to believe that there has been any difference in cost changes between the major companies, and their national market shares by customer numbers have stayed remarkably stable over the period. Regional market shares are more difficult to obtain, except to note a fall in the average share of the incumbents from 50\% in 2005 to 33\% in 2013 (DECC, 2013). Most of this fall (to 36\%) had occurred before the imposition of the NDC in 2009.

To assess whether these differences in pricing pattern are due to the NDC, we changed the cut-off dates of the two periods arbitrarily. We re-estimated the VAR model for period 1 by moving the cut-off point twelve months later, to include the period when its imposition was widely anticipated (from Jan 2005 to Jun 2009), and find that the negative causality from the incumbent to best majoraway disappears across all regions (instead we find positive causality from the incumbent to the best majoraway for 5 regions (Manweb, London, Scottish Power, Seeboard, and SWEB). Similarly, if we re-estimate the VAR model for period 2 by moving the cut-off point 6 months before the NDC was discussed (i.e. the period from Jan 2008 to Apr 2013), we find less significant positive causality from incumbent to British Gas across the regions. Whether or not we observe a distinctive change in the causalities before and after the cut-off point in our VAR model is sensitive to the periods chosen, corroborating the hypothesis that suppliers are, indeed, responding to the NDC.

However, as mentioned in section 3.1, to establish a causal relationship of price changes between incumbent and the best majoraway (both before and after the NDC) alternative reasons that could explain such movements in the price 
changes of the incumbent and best majoraway need to be excluded. Table 3 summarises our findings that the past best majoraway price changes do not add explanatory power to the incumbents' price changes, after controlling for the past incumbent price changes in the incumbent equation in these regions. In other words, the explanation runs from the incumbent to the best majoraway in these regions, but not in the reverse direction. This is true for all regions shown in table 1 and 2 except one (Yorkshire in period 1 and SWEB in period 2). Similarly, table 3 shows little evidence that price changes of the best majorsaway 'Granger Cause' those of British Gas in each region. The results in table 3 do not rule out the possibility that there might be another explanation of the movements of these price changes ${ }^{23}$, but our analysis provides strong supporting evidence for our hypothesis.

\section{Conclusion}

The analysis suggests that before the introduction of the NDC clause, the best majorsaway were broadly constraining regional incumbents' price increases. However, after the clauses were imposed, the best majorsaway's prices were much closer to those of the incumbent, so that if the incumbent accelerated its price increases, the best majoraway would follow, indicating that the constraint on incumbent price increases has weakened, with majorsaway based in other regions likely to be less aggressive outside their own home regions after the NDC. The evidence suggests that British Gas was the price leader of both the best majoraway and the incumbent in the period before the NDC. After the NDC, while the best majorsaway continued to follow British Gas, price leadership by British Gas of the incumbent is less strong. In five out of fourteen regions, the incumbent is leading British Gas, and in another five British Gas is leading the incumbent. The regional markets seem to become closer to duopolies between

\footnotetext{
${ }^{23}$ Causality established in this way would require structural assumptions with underlying theory
} behind the formulation. 
the regional incumbent and British Gas, as regional incumbents now focus more on their home regions.

Although by design the VAR model does not allow us to establish causal relationships of price changes between the suppliers, it does enable workable estimates of some underlying relationships. The estimations show that there is a change before and after the NDC in how price changes of the best majoraway are explained by the past movements of price changes of the regional incumbent. The sensitivity of the results to the timing of the cut-off point around the introduction of the NDC suggests that this is indeed the underlying cause of the change. Whereas we recognise that there could be other intervening explanations that explain the movements of price changes of both incumbent and best majoraway, the change in the pattern before and after the NDC strongly supports the hypothesis that the introduction of the NDC has changed the nature of competition and strength of rivalry in the tariff analysed. This is the main tariff used by dual fuel customers ${ }^{24}$, particularly those who are likely to switch supplier. But as predicted and, to some extent intended, the focus of competition moved after the NDC to the special offers which companies were allowed to introduce. Unfortunately the number and variety of these tariffs does not make them amenable to a simple analysis of the kind presented here.

While we cannot analyse the special tariffs, we note three aspects of this diversion of competition. The first is the encouraging message that the companies introduced them at all, suggesting a continuing appetite to segment the market and compete for some consumers, despite the potentially comfortable life of retreat to incumbent regions which the NDC offered. The second is that at the end of the special offers, consumers who took no further action would default onto regular tariffs of the kind whose analysis we report, so they may

${ }^{24}$ We have analysed electricity rather than dual fuel prices because these are the tariffs whose relative value is directly affected by the NDC, but we expect similar results from an analysis of dual fuel tariffs. 
reflect long term consumer experience, even for those who took advantage of limited time special offers. The third is that both falling switching rates and rising profits after the NDC suggest that companies were indeed competing less aggressively in the 'standard' markets following their introduction. However we believe that other remedies introduced by Ofgem at the same time, including non-discrimination clauses related to payment method $^{25}$, were likely to be procompetitive, so any dampening of competition is likely to flow from the NDC itself.

The last few years have also seen a significant increase in the number of new entrants to the industry, and in their market share. This is no doubt in response to the increasing profit levels in the sector, and such fringe entry is quite consistent with (tacit) co-ordination among the major players. The presence of the new suppliers is also a tribute to Ofgem's efforts to remove entry barriers, including some social and environmental obligations, though barriers to expansion remain ${ }^{26}$. Insofar as the large players reduce price levels in response to these new entrants, and are unable to recoup their additional costs from only one (inert) group of consumers because of non-discrimination requirements, their entry will benefit all consumers.

Ofgem's introduction of the NDC was primarily on equity grounds, to prevent companies from charging higher prices to inactive consumers in their home regions. While the differential between the standard tariffs levied in different regions has indeed fallen, the increasing profits indicate that this levelling is almost certainly at the expense of consumers out of region, rather than through lower prices to those sticky customers at home. Indeed the increase in profits by around $£ 100$ per consumer, compared with an average price differential before

\footnotetext{
${ }^{25}$ The payment related non-discrimination clauses are more likely to be procompetitive because the suppliers would agree on their 'strong' markets (see Hviid and Waddams Price 2012).

${ }^{26}$ Environmental and social obligations are applied to companies with more than 250,000 consumers
} 
the NDC of less than $£ 30^{27}$, suggests that all consumers are probably paying higher prices as a result. So while equity may have improved, this is likely to have been at the 'absolute' expense of just those consumers whom the regulator sought to protect.

In reviewing the remedies introduced after the 2008 supply probe (which included the NDC), and in response to the falling switching rates and large array of tariffs (partly generated by the NDC itself), at the end of 2013 the regulator implemented restrictions on the number of tariffs which each company could charge, in order to simplify consumer choice. These are another form of nondiscrimination clause, since they constrain the range of prices which companies can offer to potential consumers, though not between regions which was the focus of the NDC. The early consequences are, as one might expect, the withdrawal of many of the lowest priced offers, some of which had previously been taken up by vulnerable groups. The effect of these new restrictions will depend on whether the companies' appetite for competition which was revealed through their array of special offers will lead them to make good offers across the board, or whether they will follow the pattern illustrated in this paper of reducing rivalry and retreating to established markets. Pricing strategies are also affected by government intervention. The 2013-14 review of the market by the competition and regulatory authorities and referral to the Competition and Markets Authority in 2014 is a welcome opportunity to consider the market as a whole, including the likely long term effect on the competitive process of past and potential future interventions by regulators and politicians.

\footnotetext{
${ }^{27}$ Figures from Ofgem (2013) and calculated from Ofgem (2008)
} 
Table 1 Results for period 1 -before the non-discrimination clause (Jan 2005- Jun 2008)

\begin{tabular}{|c|c|c|c|c|c|c|c|c|}
\hline 1 & 2 & 3 & 4 & 5 & 6 & 7 & 8 & 9 \\
\hline Region & \multicolumn{2}{|c|}{$I_{t-p} \rightarrow M_{t}$} & \multicolumn{2}{|c|}{$B_{t-p} \rightarrow M_{t}$} & \multicolumn{2}{|c|}{$B_{t-p} \rightarrow I_{t}$} & \multicolumn{2}{|c|}{$I_{t-p} \rightarrow B_{t}$} \\
\hline & $\begin{array}{c}\text { VAR } \\
\text { coefficient }\end{array}$ & GC test & $\begin{array}{c}\text { VAR } \\
\text { coefficient }\end{array}$ & GC test & $\begin{array}{c}\text { VAR } \\
\text { coefficient }\end{array}$ & GC test & $\begin{array}{c}\text { VAR } \\
\text { coefficient }\end{array}$ & GC test \\
\hline Eastern & $\begin{array}{l}\mathrm{P}=2:- \\
0.124\end{array}$ & $\begin{array}{c}8.18 \\
(0.02)\end{array}$ & $\mathrm{P}=2: 0.301$ & $\begin{array}{l}25.80 \\
(0.00)\end{array}$ & $\mathrm{P}=1: 0.376$ & $\begin{array}{c}5.49 \\
(0.06)\end{array}$ & & \\
\hline $\begin{array}{l}\text { East } \\
\text { Midlands }\end{array}$ & $\begin{array}{l}\mathrm{P}=2:- \\
0.112\end{array}$ & $\begin{array}{c}5.59 \\
(0.06)\end{array}$ & $\mathrm{P}=2: 0.350$ & $\begin{array}{l}32.24 \\
(0.00)\end{array}$ & $\mathrm{P}=1: 0.396$ & $\begin{array}{c}6.89 \\
(0.03)\end{array}$ & & \\
\hline London & & & $\mathrm{P}=2: 0.305$ & $\begin{array}{l}23.79 \\
(0.00)\end{array}$ & & & & \\
\hline Manweb & & & $\begin{array}{l}\mathrm{P}=1: 0.168 \\
\mathrm{P}=2: 0.306\end{array}$ & $\begin{array}{l}16.41 \\
(0.00)\end{array}$ & & & & \\
\hline Midlands & $\begin{array}{l}\mathrm{P}=1:- \\
0.235\end{array}$ & $\begin{array}{l}10.80 \\
(0.01)\end{array}$ & $\mathrm{P}=2: 0.335$ & $\begin{array}{l}30.15 \\
(0.00)\end{array}$ & $\begin{array}{l}\mathrm{P}=1: 0.428 \\
\mathrm{P}=2: 0.322\end{array}$ & $\begin{array}{l}20.04 \\
(0.00)\end{array}$ & & \\
\hline Northern & $\begin{array}{l}\mathrm{P}=1:- \\
0.212\end{array}$ & $\begin{array}{l}10.51 \\
(0.01)\end{array}$ & $\mathrm{P}=2: 0.302$ & $\begin{array}{l}32.77 \\
(0.00)\end{array}$ & $\begin{array}{l}\mathrm{P}=1: 0.323 \\
\mathrm{P}=2: 0.349\end{array}$ & $\begin{array}{l}15.05 \\
(0.00)\end{array}$ & & \\
\hline Norweb & $\begin{array}{l}\mathrm{P}=2:- \\
0.209\end{array}$ & $\begin{array}{l}14.95 \\
(0.00)\end{array}$ & $\mathrm{P}=2: 0.340$ & $\begin{array}{l}39.32 \\
(0.00)\end{array}$ & $\mathrm{P}=1: 0.378$ & $\begin{array}{c}5.74 \\
(0.06)\end{array}$ & & \\
\hline
\end{tabular}

\section{Table 1 Continued}

\begin{tabular}{|c|c|c|c|c|c|c|c|c|}
\hline \multirow{2}{*}{$\frac{1}{\text { Region }}$} & 2 & 3 & 4 & 5 & 6 & 7 & 8 & 9 \\
\hline & \multicolumn{2}{|c|}{$I_{t-p} \rightarrow M_{t}$} & \multicolumn{2}{|c|}{$B_{t-p} \rightarrow M_{t}$} & \multicolumn{2}{|c|}{$B_{t-p} \rightarrow I_{t}$} & \multicolumn{2}{|c|}{$I_{t-p} \rightarrow B_{t}$} \\
\hline & $\begin{array}{c}\text { VAR } \\
\text { coefficient }\end{array}$ & GC test & $\begin{array}{c}\text { VAR } \\
\text { coefficient }\end{array}$ & GC test & $\begin{array}{c}\text { VAR } \\
\text { coefficient }\end{array}$ & GC test & $\begin{array}{c}\text { VAR } \\
\text { coefficient }\end{array}$ & GC test \\
\hline $\begin{array}{l}\text { Scottish } \\
\text { Hydro }\end{array}$ & $\begin{array}{l}\mathrm{P}=2:- \\
0.174\end{array}$ & $\begin{array}{c}6.72 \\
(0.08)\end{array}$ & $\begin{array}{l}\mathrm{P}=1: 0.450 \\
\mathrm{P}=2: 0.287\end{array}$ & $\begin{array}{l}79.76 \\
(0.00)\end{array}$ & $\mathrm{P}=2: 0.539$ & $\begin{array}{l}24.45 \\
(0.00)\end{array}$ & $\begin{array}{l}\mathrm{P}=1:- \\
0.716\end{array}$ & $\begin{array}{l}13.42 \\
(0.00)\end{array}$ \\
\hline $\begin{array}{l}\text { Scottish } \\
\text { Power }\end{array}$ & & & $\begin{array}{l}\mathrm{P}=1: 0.144 \\
\mathrm{P}=2: 0.245\end{array}$ & $\begin{array}{c}8.41 \\
(0.02)\end{array}$ & & & & \\
\hline Seeboard & & & $\mathrm{P}=2: 0.177$ & $\begin{array}{l}8.25 \\
(0.02)\end{array}$ & & & & \\
\hline Southern & & & & & $\mathrm{P}=2: 0.315$ & $\begin{array}{c}8.68 \\
(0.01)\end{array}$ & & \\
\hline SWALEC & & & & & $\mathrm{P}=2: 0.276$ & $\begin{array}{l}13.56 \\
(0.00)\end{array}$ & $\begin{array}{l}\mathrm{P}=2:- \\
0.609\end{array}$ & $\begin{array}{c}6.59 \\
(0.09)\end{array}$ \\
\hline SWEB & & & $\mathrm{P}=2: 0.202$ & $\begin{array}{l}11.44 \\
(0.00)\end{array}$ & & & & \\
\hline Yorkshire & $\begin{array}{l}\mathrm{P}=1:- \\
0.180\end{array}$ & $\begin{array}{c}6.03 \\
(0.05)\end{array}$ & $\mathrm{P}=2: 0.284$ & $\begin{array}{l}23.45 \\
(0.00)\end{array}$ & $\begin{array}{l}\mathrm{P}=1: 0.370 \\
\mathrm{P}=2: 0.432\end{array}$ & $\begin{array}{l}20.42 \\
(0.00)\end{array}$ & & \\
\hline
\end{tabular}


Column 2 reports the coefficients of price changes in the past (up to $p$ lags) of the incumbent in the best majoraway equation, i.e. how the price changes of the incumbent in the past affect current price changes of the best majoraway;

Column 4 reports the coefficients of price changes in the past (up to $p$ lags) of British Gas in the best majoraway equation, i.e. how the price changes of British Gas in the past affect current price changes of the best majoraway;

Column 6 reports the coefficients of price changes in the past (up to $p$ lags) of British Gas in the incumbent equation, i.e. how the price changes of British Gas in the past affect current price changes of the incumbent;

Column 8 reports the coefficients of price changes in the past (up to $p$ lags) of the incumbent in the British Gas equation, i.e.

how the price changes of incumbent in the past affect current price changes of British Gas;

Columns 3, 5, 7 and 9 report the corresponding Granger Causality tests;

Only significant coefficients of lagged price changes are reported in the table.

The following list shows the incumbent owner in each region:

Region

Eastern

East Midlands

London

Manweb

Midlands

Northern

Norweb

Scottish Hydro

Scottish Power

Seeboard

Southern

SWALEC

SWEB

Yorkshire
Incumbent owner

$$
\begin{gathered}
\text { E.On } \\
\text { E.On } \\
\text { EdF } \\
\text { Iberdrola } \\
\text { NPower } \\
\text { NPower } \\
\text { E.On } \\
\text { SSE } \\
\text { Iberdrola } \\
\text { EdF } \\
\text { SSE } \\
\text { SSE } \\
\text { EdF } \\
\text { NPower }
\end{gathered}
$$


Table 2 Results for period 2 after the non-discrimination clause (Sep 2009- Apr 2013)

\begin{tabular}{|c|c|c|c|c|c|c|c|c|c|c|c|c|}
\hline \multirow{2}{*}{$\frac{1}{\text { Region }}$} & 2 & 3 & $\mathbf{A}$ & 4 & 5 & \multirow{2}{*}{\begin{tabular}{|l|} 
B \\
ch
\end{tabular}} & 6 & 7 & \multirow{2}{*}{$\begin{array}{c}\mathrm{C} \\
\mathrm{ch}\end{array}$} & 8 & 9 & \multirow{2}{*}{$\begin{array}{c}\text { D } \\
\text { ch }\end{array}$} \\
\hline & \multicolumn{2}{|c|}{$I_{t-p} \rightarrow M_{t}$} & ch & \multicolumn{2}{|c|}{$B_{t-p} \rightarrow M_{t}$} & & \multicolumn{2}{|c|}{$B_{t-p} \rightarrow I_{t}$} & & \multicolumn{2}{|c|}{$I_{t-p} \rightarrow B_{t}$} & \\
\hline & $\begin{array}{c}\text { VAR } \\
\text { coeffic't }\end{array}$ & $\begin{array}{l}\mathrm{GC} \\
\text { test }\end{array}$ & & $\begin{array}{c}\text { VAR } \\
\text { coeffic't }\end{array}$ & $\begin{array}{l}\mathrm{GC} \\
\text { test }\end{array}$ & & $\begin{array}{c}\text { VAR } \\
\text { coeffic't }\end{array}$ & $\begin{array}{l}\mathrm{GC} \\
\text { test }\end{array}$ & & $\begin{array}{c}\text { VAR } \\
\text { coeffic't }\end{array}$ & $\begin{array}{l}\mathrm{GC} \\
\text { test }\end{array}$ & \\
\hline Eastern & $\begin{array}{l}P=3: \\
0.196\end{array}$ & $\begin{array}{l}16.90 \\
(0.00)\end{array}$ & + & $\begin{array}{c}\mathrm{P}=1: \\
0.366 \\
\mathrm{P}=3: \\
0.284\end{array}$ & $\begin{array}{c}9.04 \\
(0.03)\end{array}$ & & $\begin{array}{l}P=3: \\
0.624\end{array}$ & $\begin{array}{c}6.29 \\
(0.10)\end{array}$ & & $\begin{array}{l}P=3: \\
0.319\end{array}$ & $\begin{array}{l}19.47 \\
(0.00)\end{array}$ & + \\
\hline $\begin{array}{l}\text { East } \\
\text { Midlands }\end{array}$ & $\begin{array}{l}\mathrm{P}=3: \\
0.252\end{array}$ & $\begin{array}{l}21.73 \\
(0.00)\end{array}$ & + & $\begin{array}{c}\mathrm{P}=1: \\
0.417 \\
\mathrm{P}=3: \\
0.276\end{array}$ & $\begin{array}{l}10.55 \\
(0.01)\end{array}$ & & & & - & $\begin{array}{l}\mathrm{P}=3: \\
0.437\end{array}$ & $\begin{array}{l}22.79 \\
(0.00)\end{array}$ & + \\
\hline London & & & & $\begin{array}{l}\mathrm{P}=2: \\
0.324 \\
\mathrm{P}=3: \\
0.276\end{array}$ & $\begin{array}{l}12.87 \\
(0.01)\end{array}$ & & $\begin{array}{l}\mathrm{P}=1: \\
0.350 \\
\mathrm{P}=3: \\
0.422\end{array}$ & $\begin{array}{c}8.43 \\
(0.04)\end{array}$ & + & & & \\
\hline Manweb & $\begin{array}{l}\mathrm{P}=1: \\
0.421 \\
\mathrm{P}=2: \\
0.360\end{array}$ & $\begin{array}{l}24.60 \\
(0.00)\end{array}$ & + & $\begin{array}{l}P=3: \\
0.364\end{array}$ & $\begin{array}{l}19.26 \\
(0.07)\end{array}$ & & & & & $\begin{array}{l}\mathrm{P}=1: \\
0.808 \\
\mathrm{P}=2: \\
0.354 \\
\mathrm{P}=3: \\
0.321\end{array}$ & $\begin{array}{l}42.95 \\
(0.00)\end{array}$ & + \\
\hline Midlands & & & + & & & - & & & - & & & \\
\hline Northern & & & + & & & - & & & - & & & \\
\hline
\end{tabular}

Please see notes for table 1. A B C D Qualitative changes between the periods 
Table 2 Continued

\begin{tabular}{|c|c|c|c|c|c|c|c|c|c|c|c|c|}
\hline \multirow{3}{*}{$\frac{1}{\text { Region }}$} & 2 & 3 & $\mathbf{A}$ & 4 & 5 & \multirow{3}{*}{$\begin{array}{c}\text { B } \\
\text { ch }\end{array}$} & 6 & 7 & \multirow{3}{*}{$\begin{array}{l}\mathrm{C} \\
\mathrm{ch}\end{array}$} & 8 & 9 & \multirow{3}{*}{$\begin{array}{c}\text { D } \\
\text { ch }\end{array}$} \\
\hline & \multicolumn{2}{|c|}{$I_{t-p} \rightarrow M_{t}$} & ch & \multicolumn{2}{|c|}{$B_{t-p} \rightarrow M_{t}$} & & \multicolumn{2}{|c|}{$B_{t-p} \rightarrow I_{t}$} & & \multicolumn{2}{|c|}{$I_{t-p} \rightarrow B_{t}$} & \\
\hline & $\begin{array}{c}\text { VAR } \\
\text { coeffic't }\end{array}$ & $\begin{array}{l}\mathrm{GC} \\
\text { test }\end{array}$ & & $\begin{array}{c}\text { VAR } \\
\text { coeffic't }\end{array}$ & $\begin{array}{l}\mathrm{GC} \\
\text { test }\end{array}$ & & $\begin{array}{c}\text { VAR } \\
\text { coeffic't }\end{array}$ & $\begin{array}{l}\mathrm{GC} \\
\text { test }\end{array}$ & & $\begin{array}{c}\text { VAR } \\
\text { coeffic't }\end{array}$ & $\begin{array}{l}\mathrm{GC} \\
\text { test }\end{array}$ & \\
\hline Norweb & $\begin{array}{l}P=3: \\
0.209\end{array}$ & $\begin{array}{l}16.16 \\
(0.00)\end{array}$ & + & $\begin{array}{c}\mathrm{P}=1: \\
0.292 \\
\mathrm{P}=3: \\
0.163\end{array}$ & $\begin{array}{c}7.96 \\
(0.05)\end{array}$ & & $\begin{array}{l}P=3: \\
0.672\end{array}$ & $\begin{array}{l}12.35 \\
(0.01)\end{array}$ & & $\begin{array}{l}\mathrm{P}=3: \\
0.421\end{array}$ & $\begin{array}{l}25.02 \\
(0.00)\end{array}$ & + \\
\hline $\begin{array}{l}\text { Scottish } \\
\text { Hydro }\end{array}$ & $\begin{array}{l}\mathrm{P}=1:- \\
0.312 \\
\mathrm{P}=2:- \\
0.311 \\
\mathrm{P}=3:- \\
0.354\end{array}$ & $\begin{array}{l}14.28 \\
(0.00)\end{array}$ & & $\begin{array}{c}\mathrm{P}=1: \\
0.211) \\
\mathrm{P}=2: \\
0.273 \\
\mathrm{P}=3: \\
0.541\end{array}$ & $\begin{array}{l}34.71 \\
(0.00)\end{array}$ & & & & - & & & + \\
\hline $\begin{array}{l}\text { Scottish } \\
\text { Power }\end{array}$ & $\begin{array}{l}\mathrm{P}=1: \\
0.582 \\
\mathrm{P}=2: \\
0.430\end{array}$ & $\begin{array}{l}23.01 \\
(0.00)\end{array}$ & + & $\begin{array}{l}P=3: \\
0.340\end{array}$ & $\begin{array}{l}15.28 \\
(0.00)\end{array}$ & & & & & $\begin{array}{l}\mathrm{P}=1: \\
0.917 \\
\mathrm{P}=2: \\
0.474 \\
\mathrm{P}=3: \\
0.416\end{array}$ & $\begin{array}{l}28.41 \\
(0.00)\end{array}$ & + \\
\hline
\end{tabular}

Please see notes for table 1. A B C D Qualitative changes between the periods

Table 2 Continued

\begin{tabular}{|c|c|c|c|c|c|c|c|c|c|c|c|c|}
\hline \multirow{2}{*}{$\frac{1}{\text { Region }}$} & 2 & 3 & $\mathbf{A}$ & 4 & 5 & \multirow{2}{*}{$\begin{array}{c}\text { B } \\
\text { ch }\end{array}$} & 6 & 7 & \multirow{2}{*}{$\begin{array}{c}\mathrm{C} \\
\mathrm{ch}\end{array}$} & 8 & 9 & \multirow{2}{*}{$\begin{array}{c}\text { D } \\
\text { ch }\end{array}$} \\
\hline & \multicolumn{2}{|c|}{$I_{t-p} \rightarrow M_{t}$} & ch & \multicolumn{2}{|c|}{$B_{t-p} \rightarrow M_{t}$} & & \multicolumn{2}{|c|}{$B_{t-p} \rightarrow I_{t}$} & & \multicolumn{2}{|c|}{$I_{t-p} \rightarrow B_{t}$} & \\
\hline & $\begin{array}{c}\text { VAR } \\
\text { coeffic't }\end{array}$ & $\begin{array}{l}\mathrm{GC} \\
\text { test }\end{array}$ & & $\begin{array}{c}\text { VAR } \\
\text { coeffic't }\end{array}$ & $\begin{array}{l}\mathrm{GC} \\
\text { test }\end{array}$ & & $\begin{array}{c}\text { VAR } \\
\text { coeffic't }\end{array}$ & $\begin{array}{l}\mathrm{GC} \\
\text { test }\end{array}$ & & $\begin{array}{c}\text { VAR } \\
\text { coeffic't }\end{array}$ & $\begin{array}{l}\mathrm{GC} \\
\text { test }\end{array}$ & \\
\hline Seeboard & & & & $\begin{array}{l}\mathrm{P}=2: \\
0.269\end{array}$ & $\begin{array}{c}7.47 \\
(0.06)\end{array}$ & & $\begin{array}{c}\mathrm{P}=1: \\
0.589 \\
\mathrm{P}=3: \\
0.588\end{array}$ & $\begin{array}{l}25.69 \\
(0.00)\end{array}$ & + & & & \\
\hline Southern & $\begin{array}{c}\mathrm{P}=1:- \\
0.176 \\
\mathrm{P}=2:- \\
0.267\end{array}$ & $\begin{array}{l}12.90 \\
(0.01)\end{array}$ & - & $\begin{array}{c}\mathrm{P}=2: \\
0.341 \\
\mathrm{P}=3: \\
0.534\end{array}$ & $\begin{array}{l}29.13 \\
(0.00)\end{array}$ & + & & & - & & & \\
\hline
\end{tabular}




\begin{tabular}{|c|c|c|c|c|c|c|c|c|c|c|}
\hline & $\begin{array}{l}\mathrm{P}=3:- \\
0.440\end{array}$ & & & & & & & & & \\
\hline SWALEC & & & & $\begin{array}{l}\mathrm{P}=3: \\
0.450\end{array}$ & $\begin{array}{l}16.54 \\
(0.00)\end{array}$ & + & & & - & + \\
\hline SWEB & $\begin{array}{c}\mathrm{P}=2: \\
0.297\end{array}$ & $\begin{array}{c}6.30 \\
(0.10)\end{array}$ & + & $\begin{array}{l}\mathrm{P}=2: \\
0.226\end{array}$ & $\begin{array}{c}7.51 \\
(0.06)\end{array}$ & & $\begin{array}{c}\mathrm{P}=1: 0.338 \\
\mathrm{P}=3: \\
0.444\end{array}$ & $\begin{array}{l}22.17 \\
(0.01)\end{array}$ & + & \\
\hline Yorkshire & & & + & & & - & & & - & \\
\hline
\end{tabular}

Please see notes for table 1. A B C D Qualitative changes between the periods 
Table 3 Additional Tests of Granger causality from past price changes of best majoraway to current price changes of incumbent and British Gas

\begin{tabular}{|l|c|c|c|c|c|}
\hline Region & $\begin{array}{c}\text { Incumbent } \\
\text { owner }\end{array}$ & \multicolumn{2}{|c|}{ Period 1 } & \multicolumn{2}{|c|}{ Period 2 } \\
\cline { 3 - 6 } & & $M_{t-p} \rightarrow I_{t}$ & $M_{t-p} \rightarrow B_{t}$ & $M_{t-p} \rightarrow I_{t}$ & $M_{t-p} \rightarrow B_{t}$ \\
\hline & & GC test & GC test & GC test & GC test \\
\hline Eastern & E.On & $1.14(0.57)$ & $2.80(0.25)$ & $1.84(0.61)$ & $3.17(0.36)$ \\
\hline $\begin{array}{l}\text { East } \\
\text { Midlands }\end{array}$ & E.On & $0.86(0.65)$ & $3.07(0.22)$ & $1.90(0.59)$ & $2.85(0.42)$ \\
\hline London & EdF & & & & $1.77(0.62)$ \\
\hline Manweb & Iberdrola & & $4.38(0.11)$ & $1.58(0.67)$ & $3.44(0.33)$ \\
\hline Midlands & NPower & $1.55(0.46)$ & $1.54(0.47)$ & & $1.01(0.80)$ \\
\hline Northern & NPower & $4.68(0.10)$ & $0.09(0.96)$ & & $1.46(0.69)$ \\
\hline
\end{tabular}

Table 3 Continued

\begin{tabular}{|l|c|c|c|c|c|}
\hline Region & $\begin{array}{c}\text { Incumben } \\
\mathbf{t} \\
\text { owner }\end{array}$ & \multicolumn{2}{|c|}{ Period 1 } & \multicolumn{2}{|c|}{ Period 2 } \\
\cline { 3 - 6 } & $M_{t-p} \rightarrow I_{t}$ & $M_{t-p} \rightarrow B_{t}$ & $M_{t-p} \rightarrow I_{t}$ & $M_{t-p} \rightarrow B_{t}$ \\
\hline Norweb & E.On & $0.75(0.69)$ & $0.52(0.77)$ & $2.83(0.42)$ & $4.17(0.24)$ \\
\hline $\begin{array}{l}\text { Scottish } \\
\text { Hydro }\end{array}$ & SSE & $1.28(0.53)$ & $0.28(0.87)$ & $1.69(0.64)$ & $0.81(0.85)$ \\
\hline $\begin{array}{l}\text { Scottish } \\
\text { Power }\end{array}$ & Iberdrola & & $3.75(0.15)$ & $6.21(0.10)$ & $\mathbf{9 . 2 6}(\mathbf{0 . 0 3})$ \\
\hline Seeboard & EdF & & & & GC test \\
\hline Southern & SSE & & $0.22(0.89)$ & $1.06(0.79)$ & $1.76(0.62)$ \\
\hline $\begin{array}{l}\text { SWALE } \\
\text { C }\end{array}$ & SSE & & $0.49(0.78)$ & & $0.33(0.96)$ \\
\hline SWEB & EdF & & & & $1.61(0.66)$ \\
\hline Yorkshire & NPower & $\mathbf{5 . 0 7 ( 0 . 0 8 )}$ & $0.44(0.80)$ & & $1.21(0.75)$ \\
\hline
\end{tabular}

GC test reports the Granger causality test statistics on the coefficients of price changes in the past (up to $p$ lags) of the best majoraway in the incumbent/British Gas equation, i.e. how the price changes of the best majoraway in the past predict current price changes of incumbent/British Gas, controlling for past price changes of incumbent/British Gas itself, that of British Gas/incumbent and exogenous factors in the model. 


\section{References}

Cameron, D. (2012). "David Cameron Stands by 'Lowest' Energy Tariff Vow." $18^{\text {th }}$ October, http://www.bbc.co.uk/news/uk-19986929 accessed $8^{\text {th }}$ November 2013.

Davies, S., C. Waddams Price, and C. M. Wilson (2014). "Nonlinear Pricing and Tariff Differentiation: Evidence from the British Electricity Market." The Energy Journal 35 (1): $57-77$

Department of Energy and Climate Change (DECC) (2014a). "Quarterly Energy Consumer Number." https://www.gov.uk/government/statistical-data-sets/quarterlydomestic-energy-switching-statistics accessed 22nd July 2014.

Department of Energy and Climate Change (DECC) (2014b). "Table 2.4.2 Regional Variation of Payment Method for Standard Electricity." https://www.gov.uk/government/statistical-data-sets/quarterly-domestic-energy-pricestastics accessed 11th April 2014.

Flores, M. and C. Waddams Price (2013). "Consumer Behaviour in the British Retail Electricity Market." Centre for Competition Policy, Working paper \#13-10, http://competitionpolicy.ac.uk/publications/working-papers-2013.

Giulietti, M., C. Waddams Price, and M. Waterson (2005). "Consumer Choice and Competition Policy: a Study of UK Energy Markets." The Economic Journal 115.(506): 949-968.

Hviid, M., and C. Waddams Price (2012). "Non-Discrimination Clauses in the Retail Energy Sector." The Economic Journal 122(562): F236-F252

Johansen, S. (1995). Likelihood-Based Inference in Cointegrated Vector Autoregressive Models. Oxford: Oxford University Press.

Littlechild, S. (2012). "Protecting Customers or Suppliers? A Response to Ofgem's Consultation on Its Retail Market Review - Updated Domestic Proposals." https://www.ofgem.gov.uk/publications-and-updates/retail-market-review-updateddomestic-proposals

Lutkepohl, H. (2005). New Introduction to Multiple Time Series Analysis. New York: Springer.

Miliband, Ed. (2013). "Labour Would Freeze Energy Prices." 24 $4^{\text {th }}$ September, http://www.bbc.co.uk/news/uk-politics-24213366 accessed 8th November 2013

Ofgem (2008). “Energy Supply Probe-Initial Findings Report.” $6^{\text {th }}$ October, Ofgem

Ofgem (2009). “Addressing Undue Discrimination.”, 26 ${ }^{\text {th }}$ June, Ofgem

Ofgem (2011). “Typical Domestic Energy Consumption Figures.”, Factsheet 96 18.01.11. https://www.ofgem.gov.uk/ofgem-publications/64026/domestic-energy-consump-figfs.pdf accessed $11^{\text {th }}$ April 2013

Ofgem (2013). "Market Indicators." https://www.ofgem.gov.uk/gas/retailmarket/monitoring-data-and-statistics/electricity-and-gas-supply-market-indicators, accessed $19^{\text {th }}$ December 2013 
Ofgem (2014). "State of the Market Assessment." https://www.ofgem.gov.uk/publications-and-updates/state-market-assessment , accessed $29^{\text {th }}$ April 2014

Osborne, G. (2013) Autumn Statement 2013. ISBN 978-0-10-187472-4, PU1575, Cm. 8747

Evans, S., and C. Waddams Price (2004). "Charges, Costs and Market Power: the Deregulated UK Electricity Retail Market." The Energy Journal 25(3): 19-36.

Waddams, C. (2009). "Addressing Undue Discrimination: Final Proposals: Response to Ofgem's Consultation.” May. http://competitionpolicy.ac.uk/publications/responses-toconsultations accessed 3rd January 2014

Waddams Price, C., C. Webster and M. Zhu (2013). Searching and Switching: Empirical Estimates of Consumer Behaviour in Regulated Markets, Centre for Competition Policy, working paper \#13-11 


\section{Appendix:}

The following tables show the full results with the LM test (testing auto correlation in the residual terms) and LR test (testing lag length).

Table A1-Part I: Results for period 1 -before the non-discrimination clause (Jan 2005- Jun 2008)

\begin{tabular}{|c|c|c|c|c|}
\hline Region & $I_{t-p} \rightarrow M_{t}$ & $B_{t-p} \rightarrow M_{t}$ & $B_{t-p} \rightarrow I_{t}$ & $I_{t-p} \rightarrow B_{t}$ \\
\hline Eastern & $\mathrm{P}=2:-0.124(-1.58)$ & $\mathrm{P}=2: 0.301 * * *(4.64)$ & $\mathrm{P}=1: 0.376^{* * *}(2.32)$ & \\
\hline East Midlands & $\mathrm{P}=2:-0.112(-1.35)$ & $\mathrm{P}=2: 0.350 * * *(5.13)$ & $\mathrm{P}=1: 0.396 * * *(2.61)$ & \\
\hline London & $\mathrm{P}=1:-0.288 *(-1.78)$ & $\mathrm{P}=2: 0.305 * * *(4.84)$ & & \\
\hline Manweb & & $\begin{array}{l}\mathrm{P}=1: 0.168 * *(1.88) \\
\mathrm{P}=2: 0.306 * * *(3.91)\end{array}$ & & \\
\hline Midlands & $\mathrm{P}=1:-0.235 * * *(-3.12)$ & $\mathrm{P}=2: 0.335 * * *(5.48)$ & $\begin{array}{l}\mathrm{P}=1: 0.428 * * *(4.11) \\
\mathrm{P}=2: 0.322 * * *(2.53)\end{array}$ & \\
\hline Northern & $\mathrm{P}=1:-0.212 * * *(-3.03)$ & $\mathrm{P}=2: 0.302 * * *(5.72)$ & $\begin{array}{l}\mathrm{P}=1: 0.323 * * *(2.95) \\
\mathrm{P}=2: 0.349 * * *(2.83)\end{array}$ & \\
\hline Norweb & $\mathrm{P}=2:-0.209 * * *(-3.10)$ & $\mathrm{P}=2: 0.340 * * *(6.01)$ & $\mathrm{P}=1: 0.378 * * *(2.28)$ & \\
\hline Scottish Hydro & $\mathrm{P}=2:-0.174 * *(-2.00)$ & $\begin{array}{l}\mathrm{P}=1: 0.450 * * *(8.79) \\
\mathrm{P}=2: 0.287 * * *(3.31)\end{array}$ & $\mathrm{P}=2: 0.539 * * *(2.83)$ & $\mathrm{P}=1:-0.716^{* * *}(-2.75)$ \\
\hline Scottish Power & & $\begin{array}{l}\mathrm{P}=1: 0.144 *(1.65) \\
\mathrm{P}=2: 0.245 * * *(2.76)\end{array}$ & & \\
\hline Seeboard & & $\mathrm{P}=2: 0.177 * * *(2.87)$ & $\mathrm{P}=2: 0.151 *(1.64)$ & \\
\hline Southern & & & $\mathrm{P}=2: 0.315 * * *(2.67)$ & $\mathrm{P}=2:-0.488 * *(-1.94)$ \\
\hline SWALEC & $\mathrm{P}=2:-0.234^{*}(-1.70)$ & $\mathrm{P}=2: 0.154 *(1.82)$ & $\mathrm{P}=2: 0.276^{* * *}(3.43)$ & $\mathrm{P}=2:-0.609 * *(-2.10)$ \\
\hline SWEB & & $\mathrm{P}=2: 0.202 * * *(3.35)$ & & \\
\hline Yorkshire & $\mathrm{P}=1:-0.180 * *(-2.40)$ & $\mathrm{P}=2: 0.284 * * *(4.82)$ & $\begin{array}{l}\mathrm{P}=1: 0.370 * * *(3.42) \\
\mathrm{P}=2: 0.432 * * *(3.23)\end{array}$ & \\
\hline
\end{tabular}


Table A1-Part II: LM and LR tests

\begin{tabular}{|c|c|c|c|c|}
\hline Region & LM test (chi2) & LR test & No. of Obs. & R-sq \\
\hline Eastern & $\begin{array}{l}\mathrm{P}=1: 4.63(0.86) \\
\mathrm{P}=2: 10.11(0.34)\end{array}$ & $\begin{array}{l}\mathrm{P}=2 *: 33.60(0.00) \\
\mathrm{P}=1: 19.76(0.02)\end{array}$ & 39 & $\begin{array}{l}\text { E-eq: } 0.62 \\
\text { I-eq: } 0.32 \\
\text { B-eq: } 0.29\end{array}$ \\
\hline East Midlands & $\begin{array}{l}\mathrm{P}=1: 5.49(0.79) \\
\mathrm{P}=2: 9.11(0.43)\end{array}$ & $\begin{array}{l}\mathrm{P}=2^{*}: 38.90(0.00) \\
\mathrm{P}=1: 20.51(0.02)\end{array}$ & 39 & $\begin{array}{l}\text { E-eq: } 0.62 \\
\text { I-eq: } 0.32 \\
\text { B-eq: } 0.22\end{array}$ \\
\hline London & $\begin{array}{l}\mathrm{P}=1: 11.47(0.24) \\
\mathrm{P}=2: 8.77(0.46)\end{array}$ & $\begin{array}{l}\mathrm{P}=2 *: 26.77(0.00) \\
\mathrm{P}=1: 9.27(0.02)\end{array}$ & 39 & $\begin{array}{l}\text { E-eq: } 0.48 \\
\text { I-eq: } 0.28 \\
\text { B-eq: } 0.22 \\
\end{array}$ \\
\hline Manweb & $\begin{array}{l}\mathrm{P}=1: 13.41(0.14) \\
\mathrm{P}=2: 16.74(0.06)\end{array}$ & $\begin{array}{l}\mathrm{P}=2 *: 20.55(0.00) \\
\mathrm{P}=1: 32.64(0.02)\end{array}$ & 39 & $\begin{array}{l}\text { E-eq: } 0.61 \\
\text { I-eq: } 0.44 \\
\text { B-eq: } 0.20\end{array}$ \\
\hline Midlands & $\begin{array}{l}\mathrm{P}=1: 5.59(0.78) \\
\mathrm{P}=2: 6.53(0.69)\end{array}$ & $\begin{array}{l}\mathrm{P}=2 *: 32.76(0.00) \\
\mathrm{P}=1: 18.42(0.03)\end{array}$ & 39 & $\begin{array}{l}\text { E-eq: } 0.52 \\
\text { I-eq: } 0.44 \\
\text { B-eq: } 0.18\end{array}$ \\
\hline Northern & $\begin{array}{l}\mathrm{P}=1: 9.75(0.38) \\
\mathrm{P}=2: 3.77(0.93)\end{array}$ & $\begin{array}{l}\mathrm{P}=2 *: 41.78(0.00) \\
\mathrm{P}=1: 18.97(0.03)\end{array}$ & 39 & $\begin{array}{ll}\text { E-eq: } & 0.50 \\
\text { I-eq: } 0.46 \\
\text { B-eq: } 0.16\end{array}$ \\
\hline
\end{tabular}

Table A1-Part II Continued

\begin{tabular}{|l|l|l|c|c|}
\hline Region & \multicolumn{1}{|c|}{ LM test (chi2) } & \multicolumn{1}{|c|}{ LR test } & No. of Obs. & \multicolumn{1}{c|}{ R-sq } \\
\hline Norweb & $\begin{array}{l}\mathrm{P}=1: 9.75(0.38) \\
\mathrm{P}=2: 11.84(0.22)\end{array}$ & $\begin{array}{l}\mathrm{P}=2 *: 45.35(0.00) \\
\mathrm{P}=1: 17.66(0.04)\end{array}$ & 39 & $\begin{array}{l}\text { E-eq: } 0.60 \\
\text { I-eq: } 0.27 \\
\text { B-eq: } 0.16\end{array}$ \\
\hline Scottish Hydro & $\begin{array}{l}\mathrm{P}=1: 8.39(0.49) \\
\mathrm{P}=2: 7.44(0.59)\end{array}$ & $\begin{array}{l}\mathrm{P}=3 *: 26.32(0.00) \\
\mathrm{P}=2: 31.41(0.00)\end{array}$ & 38 & $\begin{array}{l}\text { E-eq: } 0.73 \\
\text { I-eq: } 0.63 \\
\text { B-eq: } 0.32\end{array}$ \\
\hline Scottish Power & $\begin{array}{l}\mathrm{P}=1: 14.53(0.11) \\
\mathrm{P}=2: 6.82(0.66)\end{array}$ & $\begin{array}{l}\mathrm{P}=2 *: 23.88(0.01) \\
\mathrm{P}=1: 6.75(0.66)\end{array}$ & 39 & $\begin{array}{l}\text { E-eq: } 0.42 \\
\text { I-eq: } 0.21 \\
\text { B-eq: } 0.15\end{array}$ \\
\hline Seeboard & $\begin{array}{l}\mathrm{P}=1: 5.38(0.80) \\
\mathrm{P}=2: 4.14(0.91)\end{array}$ & $\begin{array}{l}\mathrm{P}=2 *: 21.73(0.01) \\
\mathrm{P}=1: 8.50(0.49)\end{array}$ & 39 & $\begin{array}{l}\text { E-eq: } 0.31 \\
\text { I-eq: } 0.25 \\
\text { B-eq: } 0.07\end{array}$ \\
\hline Southern & $\begin{array}{l}\mathrm{P}=1: 11.05(0.27) \\
\mathrm{P}=2: 9.13(0.43)\end{array}$ & $\begin{array}{l}\mathrm{P}=2 *: 28.30(0.00) \\
\mathrm{P}=1: 2.52(0.98)\end{array}$ & 39 & $\begin{array}{l}\text { E-eq: } 0.25 \\
\text { I-eq: } 0.44 \\
\text { B-eq: } 0.15\end{array}$ \\
\hline
\end{tabular}




\begin{tabular}{|l|l|l|c|l|}
\hline SWALEC & $\begin{array}{l}\mathrm{P}=1: 5.18(0.82) \\
\mathrm{P}=2: 11.80(0.23)\end{array}$ & $\begin{array}{l}\mathrm{P}=3: 23.89(0.00) \\
\mathrm{P}=2 *: 13.93(0.12)\end{array}$ & 38 & $\begin{array}{l}\text { E-eq: } 0.24 \\
\text { I-eq: } 0.54 \\
\text { B-eq: } 0.26\end{array}$ \\
\hline SWEB & $\begin{array}{l}\mathrm{P}=1: 5.56(0.78) \\
\mathrm{P}=2: 3.79(0.92)\end{array}$ & $\begin{array}{l}\mathrm{P}=2 *: 16.72(0.05) \\
\mathrm{P}=1: 6.63(0.68)\end{array}$ & 39 & $\begin{array}{l}\text { E-eq: } 0.34 \\
\text { I-eq: } 0.24 \\
\text { B-eq: } 0.10\end{array}$ \\
\hline Yorkshire & $\begin{array}{l}\mathrm{P}=1: 5.36(0.80) \\
\mathrm{P}=2: 4.45(0.88)\end{array}$ & $\begin{array}{l}\mathrm{P}=2 *: 25.67(0.01) \\
\mathrm{P}=1: 23.78(0.01)\end{array}$ & 39 & $\begin{array}{l}\text { E-eq: } 0.24 \\
\text { I-eq: } 0.54 \\
\text { B-eq: } 0.26\end{array}$ \\
\hline
\end{tabular}

- A VAR model is a seemingly unrelated regression model with the same endogenous explanatory variables ( $p$ lags of price changes of best majoraway, incumbent and British Gas in our case) in each equation, i.e. the equation of price changes of best majoraway, incumbent and British Gas.

- $\quad I_{t-p} \rightarrow M_{t}$ column report the coefficients of price changes in the past (up to $p$ lags) of incumbent in the best majoraway equation, i.e. how the price changes of incumbent in the past affect current price changes of best majoraway. T-statistics are reported in the brackets. ***, ** and * indicates statistical significance level at $1 \%, 5 \%$ and $10 \%$ respectively.

- $\quad B_{t-p} \rightarrow M_{t}$ column report the coefficients of price changes in the past (up to $p$ lags) of British Gas in the best majoraway equation, i.e. how the price changes of British Gas in the past affect current price changes of best majoraway. T-statistics are reported in the brackets. ***, ** and * indicates statistical significance level at $1 \%, 5 \%$ and $10 \%$ respectively.

- $\quad B_{t-p} \rightarrow I_{t}$ column report the coefficients of price changes in the past (up to $p$ lags) of British Gas in the incumbent equation, i.e. how the price changes of British Gas in the past affect current price changes of incumbent. T-statistics are reported in the brackets. ***, ** and * indicates statistical significance level at $1 \%, 5 \%$ and $10 \%$ respectively.

- $\quad I_{t-p} \rightarrow B_{t}$ column report the coefficients of price changes in the past (up to $p$ lags) of incumbent in the British Gas equation, i.e. how the price changes of incumbent in the past affect current price changes of British Gas. T-statistics are reported in the brackets. ***, ** and * indicates statistical significance level at $1 \%, 5 \%$ and $10 \%$ respectively.

- Only significant coefficients of lagged price changes are reported in the table.

- LM test column report P-values of the test of autocorrelation in the residual and the null hypothesis is that there is no autocorrelation at lag $p$.

- $\quad$ LR test column report the log likelihood ratio test post estimation, starting with the model with most lags. For a given lag $p$, the LR test compares a VAR with $p$ lags with one with $p-1$ lags., the null hypothesis is that all the coefficients on the pth lags of the endogenous variables are zero. P-values are reported in brackets.* indicates the optimal lag length which is the number of lags selected for estimation except in region 12. In region 12, total number of 3 lags is used to ensure 0 auto-correlation in the disturbance term.

- $\quad$ R-sq column report the R-sq of each equation. E-eq, I-eq and B-eq refer to the best majoraway equation, the incumbent equation and the British Gas equation. 
Table A2-Part I: Results for period 2 -after the non-discrimination clause (Sep 2009- Apr 2013)

\begin{tabular}{|l|c|c|c|c|}
\hline Region & $I_{t-p} \rightarrow E_{t}$ & $B_{t-p} \rightarrow M_{t}$ & $B_{t-p} \rightarrow I_{t}$ & $I_{t-p} \rightarrow B_{t}$ \\
\hline Eastern & $\mathrm{P}=3: 0.196^{* * *}(4.00)$ & $\begin{array}{l}\mathrm{P}=1: 0.366^{* * *}(2.53) \\
\mathrm{P}=3: 0.284^{* *}(1.96)\end{array}$ & $\mathrm{P}=3: 0.624^{*}(1.65)$ & $\mathrm{P}=3: 0.319^{* * *}(4.40)$ \\
\hline East Midlands & $\mathrm{P}=3: 0.252^{* * *}(4.58)$ & $\begin{array}{l}\mathrm{P}=1: 0.417^{* * *}(2.98) \\
\mathrm{P}=3: 0.276^{*}(1.93)\end{array}$ & & $\mathrm{P}=3: 0.437 * * *(4.75)$ \\
\hline London & & $\mathrm{P}=2: 0.324^{* * *}(2.81)$ & $\begin{array}{l}\mathrm{P}=1: 0.350^{* *}(2.17) \\
\mathrm{P}=3: 0.276^{* *}(2.07)\end{array}$ & \\
\hline Manweb & $\mathrm{P}=3: 0.422^{* *}(2.52)$ & \\
& $\mathrm{P}=2: 0.421^{* * *}(4.65)$ & $\mathrm{P}=3: 0.364^{* * *}(3.42)$ & & $\begin{array}{l}\mathrm{P}=1: 0.808^{* * *}(6.38) \\
\mathrm{P}=2: 0.354^{* *}(2.01) \\
\mathrm{P}=3: 0.321^{* * *}(1.98)\end{array}$ \\
\hline Midlands & & & & \\
\hline Northern & & $\mathrm{P}=3: 0.325^{*}(1.82)$ & & \\
\hline Norweb & $\mathrm{P}=3: 0.209^{* * *}(3.84)$ & $\mathrm{P}=1: 0.292^{* *}(2.23)$ & $\mathrm{P}=3: 0.672^{* * *}(3.25)$ & $\mathrm{P}=3: 0.421^{* * *}(4.98)$ \\
\hline
\end{tabular}

Table A2-Part I Continued

\begin{tabular}{|c|c|c|c|c|}
\hline Region & $I_{t-p} \rightarrow E_{t}$ & $B_{t-p} \rightarrow M_{t}$ & $B_{t-p} \rightarrow I_{t}$ & $I_{t-p} \rightarrow B_{t}$ \\
\hline Scottish Hydro & $\begin{array}{l}\mathrm{P}=1:-0.312 * * *(-3.16) \\
\mathrm{P}=2:-0.311 * * *(-2.59) \\
\mathrm{P}=3:-0.354 * * *(-2.93)\end{array}$ & $\begin{array}{l}\mathrm{P}=1: 0.211^{* *}(1.97) \\
\mathrm{P}=2: 0.273^{* * *}(2.54) \\
\mathrm{P}=3: 0.541^{* * *}(5.66)\end{array}$ & & \\
\hline Scottish Power & $\begin{array}{l}\mathrm{P}=1: 0.582 * * *(4.59) \\
\mathrm{P}=2: 0.430 * * *(2.79)\end{array}$ & $\mathrm{P}=3: 0.340 * * *(2.69)$ & $\mathrm{P}=1: 0.331 * *(2.21)$ & $\begin{array}{l}\mathrm{P}=1: 0.917 * * *(5.11) \\
\mathrm{P}=2: 0.474 * *(2.16) \\
\mathrm{P}=3: 0.416^{* *}(2.22)\end{array}$ \\
\hline Seeboard & $\mathrm{P}=2: 0.290 * *(2.03)$ & $\mathrm{P}=2: 0.269^{*}(1.86)$ & $\begin{array}{l}\mathrm{P}=1: 0.589^{* * *}(4.00) \\
\mathrm{P}=3: 0.588^{* * *}(4.22)\end{array}$ & \\
\hline Southern & $\begin{array}{l}\mathrm{P}=1:-0.176 *(-1.66) \\
\mathrm{P}=2:-0.267 * *(-2.09) \\
\mathrm{P}=3:-0.440 * * *(-3.56)\end{array}$ & $\begin{array}{l}\mathrm{P}=2: 0.341 * * *(2.92) \\
\mathrm{P}=3: 0.534 * * *(5.01)\end{array}$ & & \\
\hline SWALEC & $\begin{array}{l}\mathrm{P}=1:-0.252 * *(-2.00) \\
\mathrm{P}=2:-0.273 *(-1.86) \\
\mathrm{P}=3:-0.262 *(-1.78)\end{array}$ & $\mathrm{P}=3: 0.450 * * *(4.02)$ & & \\
\hline SWEB & $\mathrm{P}=2: 0.297 * *(2.09)$ & $\mathrm{P}=2: 0.226^{* *}(2.10)$ & $\begin{array}{l}\mathrm{P}=1: 0.338^{* *}(3.08) \\
\mathrm{P}=3: 0.444^{* * *}(4.26)\end{array}$ & \\
\hline Yorkshire & & & & \\
\hline
\end{tabular}


Table A2-Part II: LM and LR tests

\begin{tabular}{|c|c|c|c|c|}
\hline Region & LM test (chi2) & LR test & No. of Obs & R-sq \\
\hline Eastern & $\begin{array}{l}\mathrm{P}=1: 14.05(0.12) \\
\mathrm{P}=2: 12.01(0.21)\end{array}$ & $\begin{array}{l}\mathrm{P}=3 *: 33.62(0.00) \\
\mathrm{P}=2: 6.01(0.74)\end{array}$ & 44 & $\begin{array}{l}\text { E-eq: } 0.44 \\
\text { I-eq: } 0.39 \\
\text { B-eq: } 0.38\end{array}$ \\
\hline East Midlands & $\begin{array}{l}\mathrm{P}=1: 11.18(0.26) \\
\mathrm{P}=2: 11.27(0.26)\end{array}$ & $\begin{array}{l}\mathrm{P}=3 *: 36.91(0.00) \\
\mathrm{P}=2: 8.44(0.49)\end{array}$ & 44 & $\begin{array}{l}\text { E-eq: } 0.48 \\
\text { I-eq: } 0.34 \\
\text { B-eq: } 0.41\end{array}$ \\
\hline London & $\begin{array}{l}\mathrm{P}=1: 8.75(0.46) \\
\mathrm{P}=2: 6.21(0.72)\end{array}$ & $\begin{array}{l}\mathrm{P}=3 *: 17.55(0.04) \\
\mathrm{P}=2: 24.51(0.00)\end{array}$ & 44 & $\begin{array}{l}\text { E-eq: } 0.37 \\
\text { I-eq: } 0.29 \\
\text { B-eq: } 0.17\end{array}$ \\
\hline Manweb & $\begin{array}{l}\mathrm{P}=1: 10.91(0.28) \\
\mathrm{P}=2: 2.58(0.98)\end{array}$ & $\begin{array}{l}\mathrm{P}=3 *: 36.34(0.00) \\
\mathrm{P}=2: 12.80(0.17)\end{array}$ & 44 & $\begin{array}{l}\text { E-eq: } 0.54 \\
\text { I-eq: } 0.26 \\
\text { B-eq: } 0.54\end{array}$ \\
\hline Midlands & $\begin{array}{l}\mathrm{P}=1: 3.63(0.93) \\
\mathrm{P}=2: 4.78(0.85)\end{array}$ & $\begin{array}{l}\mathrm{P}=3^{*}: 19.80(0.02) \\
\mathrm{P}=2: 10.19(0.34)\end{array}$ & 44 & $\begin{array}{l}\text { E-eq: } 0.17 \\
\text { I-eq: } 0.30 \\
\text { B-eq: } 0.15\end{array}$ \\
\hline Northern & $\begin{array}{l}\mathrm{P}=1: 4.70(0.86) \\
\mathrm{P}=2: 9.13(0.43)\end{array}$ & $\begin{array}{l}\mathrm{P}=3^{*}: 29.65(0.01) \\
\mathrm{P}=2: 11.21(0.26)\end{array}$ & 44 & $\begin{array}{ll}\text { E-eq: } 0.20 \\
\text { I-eq: } 0.33 \\
\text { B-eq: } 0.15\end{array}$ \\
\hline Norweb & $\begin{array}{l}\mathrm{P}=1: 10.61(0.30) \\
\mathrm{P}=2: 6.23(0.72)\end{array}$ & $\begin{array}{l}\mathrm{P}=3^{*}: 40.40(0.00) \\
\mathrm{P}=2: 6.42(0.70)\end{array}$ & 44 & $\begin{array}{l}\text { E-eq: } 0.45 \\
\text { I-eq: } 0.38 \\
\text { B-eq: } 0.43\end{array}$ \\
\hline
\end{tabular}

Table A2-Part II Continued

\begin{tabular}{|c|c|c|c|c|}
\hline Region & LM test (chi2) & LR test & No. of Obs & R-sq \\
\hline Scottish Hydro & $\begin{array}{l}\mathrm{P}=1: 8.39(0.50) \\
\mathrm{P}=2: 10.92(0.28)\end{array}$ & $\begin{array}{l}\mathrm{P}=3 *: 38.79(0.00) \\
\mathrm{P}=2: 7.10(0.63)\end{array}$ & 44 & $\begin{array}{l}\text { E-eq: } 0.49 \\
\text { I-eq: } 0.31 \\
\text { B-eq: } 0.17\end{array}$ \\
\hline Scottish Power & $\begin{array}{l}\mathrm{P}=1: 9.11(0.43) \\
\mathrm{P}=2: 4.64(0.86)\end{array}$ & $\begin{array}{l}\mathrm{P}=3 *: 27.01(0.00) \\
\mathrm{P}=2: 18.39(0.03)\end{array}$ & 44 & $\begin{array}{l}\text { E-eq: } 0.48 \\
\text { I-eq: } 0.39 \\
\text { B-eq: } 0.46\end{array}$ \\
\hline Seeboard & $\begin{array}{l}\mathrm{P}=1: 7.40(0.60) \\
\mathrm{P}=2: 4.58(0.87)\end{array}$ & $\begin{array}{l}\mathrm{P}=3 *: 25.41(0.00) \\
\mathrm{P}=2: 25.82(0.00)\end{array}$ & 44 & $\begin{array}{l}\text { E-eq: } 0.34 \\
\text { I-eq: } 0.48 \\
\text { B-eq: } 0.14\end{array}$ \\
\hline
\end{tabular}




\begin{tabular}{|c|c|c|c|c|}
\hline Southern & $\begin{array}{l}\mathrm{P}=1: 8.11(0.52) \\
\mathrm{P}=2: 10.72(0.30)\end{array}$ & $\begin{array}{l}\mathrm{P}=3^{*}: 37.09(0.11) \\
\mathrm{P}=2: 8.88(0.49)\end{array}$ & 44 & $\begin{array}{l}\text { E-eq: } 0.45 \\
\text { I-eq: } 0.33 \\
\text { B-eq: } 0.22\end{array}$ \\
\hline SWALEC & $\begin{array}{l}\mathrm{P}=1: 6.51(0.69) \\
\mathrm{P}=2: 8.11(0.52)\end{array}$ & $\begin{array}{l}\mathrm{P}=3^{*}: 26.57(0.00) \\
\mathrm{P}=2: 7.84(0.55)\end{array}$ & 44 & $\begin{array}{l}\text { E-eq: } 0.33 \\
\text { I-eq: } 0.31 \\
\text { B-eq: } 0.15\end{array}$ \\
\hline SWEB & $\begin{array}{l}\mathrm{P}=1: 4.98(0.84) \\
\mathrm{P}=2: 4.48(0.88)\end{array}$ & $\begin{array}{l}\mathrm{P}=3^{*}: 24.44(0.00) \\
\mathrm{P}=2: 19.64(0.02)\end{array}$ & 44 & $\begin{array}{l}\text { E-eq: } 0.33 \\
\text { I-eq: } 0.45 \\
\text { B-eq: } 0.13\end{array}$ \\
\hline Yorkshire & $\begin{array}{l}\mathrm{P}=1: 5.10(0.82) \\
\mathrm{P}=2: 8.80(0.46)\end{array}$ & $\begin{array}{l}\mathrm{P}=3^{*}: 25.72(0.00) \\
\mathrm{P}=2: 9.81(0.37)\end{array}$ & 44 & $\begin{array}{l}\text { E-eq: } 0.18 \\
\text { I-eq: } 0.31 \\
\text { B-eq: } 0.13 \\
\end{array}$ \\
\hline
\end{tabular}

